\title{
STUDIES OF DYNAMIC CONTACT OF CERAMICS AND ALLOYS FOR ADVANCED HEAT ENGINES
}

\author{
P. A. Gaydos and K. F. Dufrane
}

Date Published: June 1993

\section{FINAL REPORT}

\author{
Prepared by \\ Batelle \\ 505 King Avenue \\ Columbus, Ohio 43201-2693 \\ Under Subcontract \\ $86 \mathrm{X}-00216 \mathrm{C}$
}

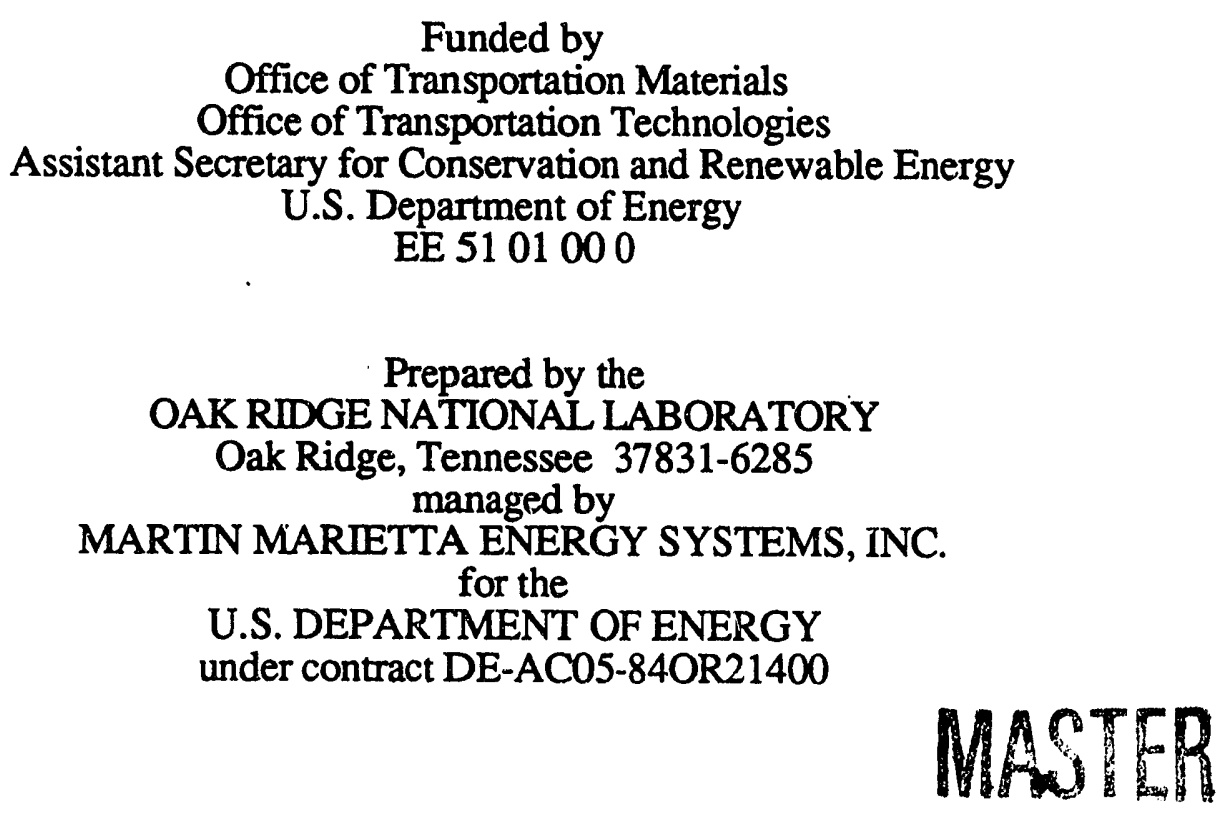




\section{TABLE OF CONTENTS}

\section{Page}

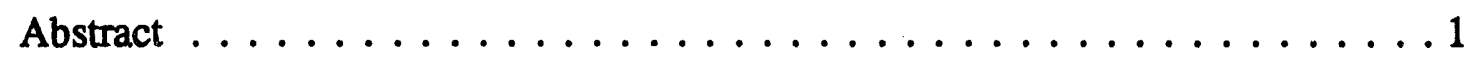

Introduction $\ldots \ldots \ldots \ldots \ldots \ldots \ldots \ldots \ldots \ldots \ldots \ldots \ldots \ldots \ldots$

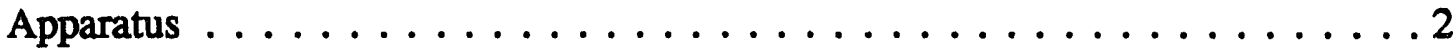

Experimental Procedures $\ldots \ldots \ldots \ldots \ldots \ldots \ldots \ldots \ldots \ldots$

Material Selection $\ldots \ldots \ldots \ldots \ldots \ldots \ldots \ldots \ldots$

Modifications for Testing Curved Specimens $\ldots \ldots \ldots \ldots \ldots \ldots$

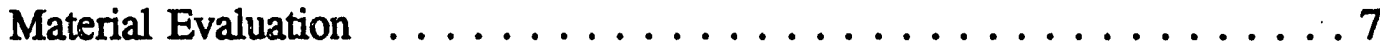

Results and Discussion $\ldots \ldots \ldots \ldots \ldots \ldots \ldots \ldots$

Baseline Wear Goal . . . . . . . . . . . . . . . . 9

Summary of Previous Studies . . . . . . . . . . . . 11

Materials from Diesel Engine Manufacturers . . . . . . . . . 11

Wear of Ion-Implanted Silicon Nitride $\ldots \ldots \ldots \ldots \ldots \ldots \ldots$

Conclusions . . . . . . . . . . . . . . . . . . . 19

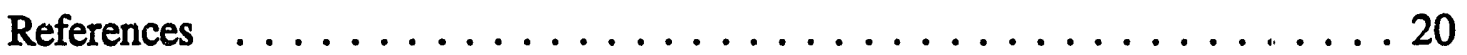




\section{LIST OF FIGURES}

Page

Figure 1. Specimen configuration $\ldots \ldots \ldots \ldots \ldots \ldots \ldots \ldots$

Figure 2. Photograph of wear apparatus $\ldots \ldots \ldots \ldots \ldots \ldots \ldots$

Figure 3. Curved ring specimen holder $\ldots \ldots \ldots \ldots \ldots \ldots \ldots \ldots$

Figure 4. Baseline wear results $\ldots \ldots \ldots \ldots \ldots \ldots \ldots \ldots$

Figure 5. The best material combinations from earlier test phases $\ldots \ldots \ldots 12$

Figure 6. Ring wear factors of specimens provided by Caterpillar . . . . . 14

Figure 7. Ring wear factors of materials combinations recommended by Cummins . . . . . . . . . . . . . 15

Figure 8. Summary of test results $\ldots \ldots \ldots \ldots \ldots \ldots \ldots \ldots$

Figure 9. Ring wear factors of silicon nitride with and without ion-implantation . . . . . . . . . . . . 18

\section{LIST OF TABLES}

Table 1 . Summary of Testing Conditions $\ldots \ldots \ldots \ldots \ldots$

Table 2. Materials used in this study $\ldots \ldots \ldots \ldots \ldots \ldots \ldots$ 


\title{
STUDIES OF DYNAMIC CONTACT OF CERAMICS AND ALLOYS FOR ADVANCED HEAT ENGINES*
}

\begin{abstract}
Advanced materials and coatings for low heat rejection engines have been investigated for almost a decade. Much of the work has concentrated on the critical wear interface between the piston ring and cylinder liner. Simplified bench tests have identified families of coatings with high temperature wear performance that could meet or exceed that of conventional engine materials at today's operating temperatures. More recently, engine manufacturers have begun to optimize material combinations and manufacturing processes so that the materials not only have promising friction and wear performance but are practical replacements for current materials from a materials and manufacturing cost standpoint.

In this study, the advanced materials supplied by major diesel engine manufacturers were evaluated in an experimental apparatus that simulates many of the in-cylinder conditions of a low heat rejection diesel engine. Results include ring wear factors and average dynamic friction coefficients measured at intervals during the test. These results are compared with other advanced materials tested in the past as well as the baseline wear of current engines. Both fabricated specimens and sections of actual ring and cylinder liners were used in the testing. Observations and relative friction and wear performance of the individual materials are provided.
\end{abstract}

\section{Introduction}

By reducing the amount of heat rejected through an engine's cooling system, more usable heat is trapped in the exhaust. By using this excess energy that would otherwise be lost to the environment, gains in engine efficiency can be obtained. Decreasing the amount of heat lost through the cooling system can be accomplished by reducing or eliminating coolant flow, insulating the combustion chamber surfaces, or a combination of both. The extra energy contained in the hotter exhaust gases can then be used for turbocharging and turbocompounding to increase the fuel efficiency of the engines. With these engine changes, top ring

\footnotetext{
Research sponsored by the U.S. Department of Energy, Assistant Secretary for Conservation and Renewable Energy, Office of Transportation Technologies, as part of the Ceramic Technology Project of the Materials Development Program, under contract DE-ACO5-840R21400 with Martin Marietta Energy Systems, Inc.
} 
reversal temperatures can easily exceed $300 \mathrm{C}$. Thise temperatures negatively affect the material properties of metallic components and quickly degrade conventional liquid lubricants.

Above their normal operating temperature, conventional fluids can provide only marginal lubrication up to about $260 \mathrm{C}^{(1)}$. At these temperatures, metallic piston rings and cylinder liners experience wear at least 100 times higher than the wear occurring under normal engine operating temperatures ${ }^{(2)}$. Ceramics as a class of materials offer a possible solution to the wear in this critical interface. High hardness, corrosion resistance, strength at elevated temperatures, and high elastic moduli are attractive ceramic properties not generally available in metals, which could be expected to compensate at least partially for the marginal liquid lubrication at elevated temperatures.

Monolithic ceramics and coatings have shown vastly improved wear performance over conventional piston ring and cylinder liner materials at elevated temperatures. Using a controlled laboratory apparatus which simulates the loads, speeds, and environment of advanced heat engines, the relative friction and wear performance of potential replacement materials have been evaluated. The high temperature wear of some ceramic materials is low enough that component life of ceramic piston rings and cylinder liners could equal that of current diesel engines ${ }^{(3)}$.

The study described in this paper centers on additional materials evaluations for the piston ring/cylinder liner application. Advanced materials evaluated in this current work were selected by Caterpillar, Inc. and Cummins Engine Co. not only for their low wear resistance but also from the practical production standpoints of materials and manufacturing costs. Wear specimens were either coatings applied to specially prepared substrates or they were sections cut from coated piston rings and cylinder liners. Lastly, wear tests were conducted to see if Radioactive Ion Implantation (RII); a process that shows promise in monitoring engine component wear in situ, would affect the wear performance of the implanted material.

\section{Apparatus}

The experimental apparatus used in this study was designed to reproduce most of the operating conditions of a ring/cylinder interface at temperatures to $650 \mathrm{C}$. The specimen configuration shown in Figure 1 uses the original flat "liner" specimens and straight "ring" specimens. Special fixtures that could accommodate curved ring and cylinder specimens cut from actual engine components were also used in this study. The two cylinder specimens measured $13 \times 32 \times 125 \mathrm{~mm}$ and had either a flat or concave wear surface. On: liner specimen was fixed, while the other was mounted on a slideway to permit applying contact loads up to $50 \mathrm{~N} / \mathrm{mm}$ and was adjustable to maintain parallelism between the liner specimens. For a comparison of ring contact loading, the peak 


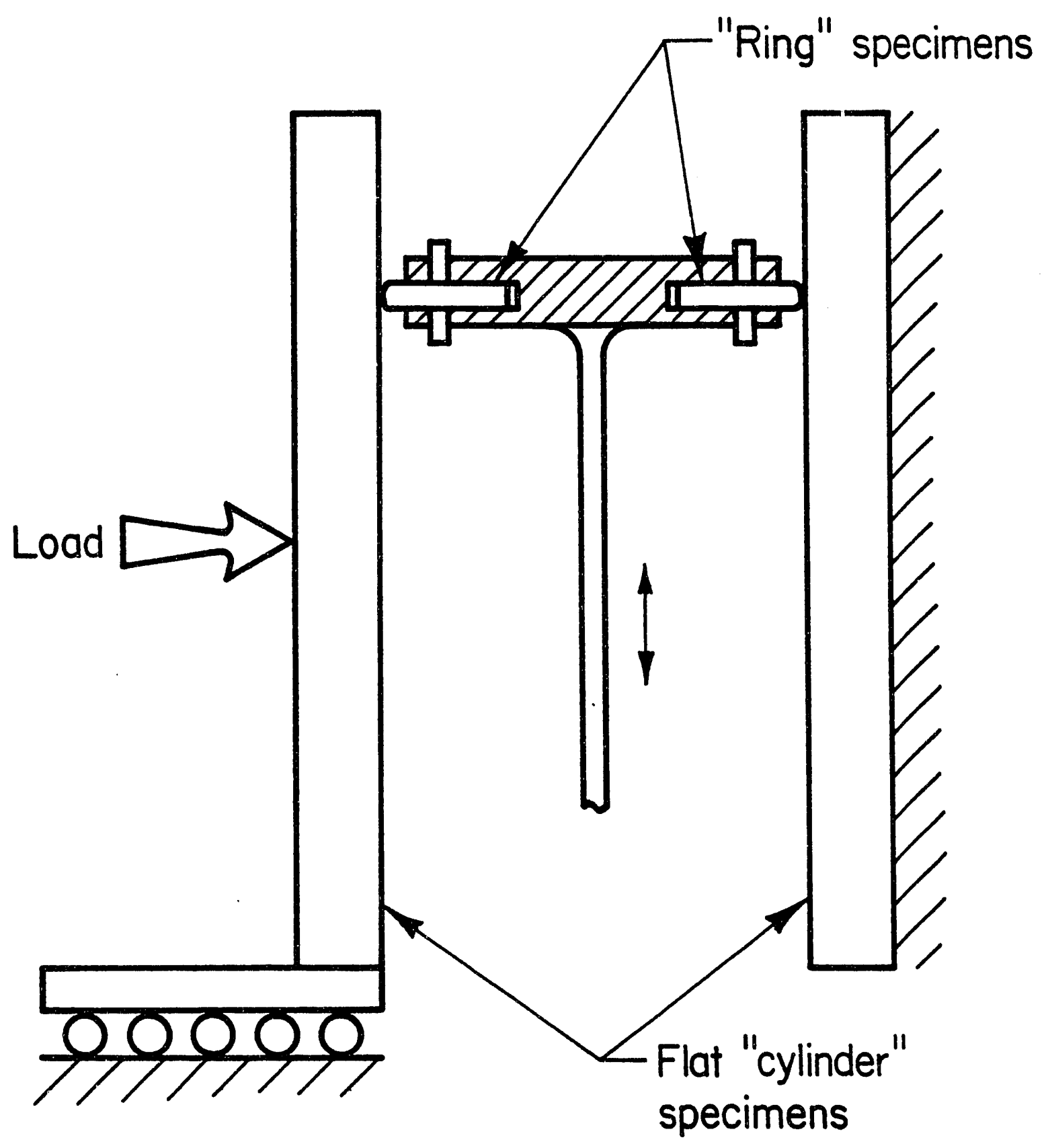

Figure 1. Specimen configuration. 
ring loading on a typical diesel engine is approximately $35 \mathrm{~N} / \mathrm{mm}$. The straight ring specimens were $19 \mathrm{ram}$ long, $19 \mathrm{~mm}$ wide, and $3.2 \mathrm{~mm}$ thick. A 32-mmradius crown was ground on the ring specimen to provide an initial cylinder-onflat line contact geometry. The ring specimens were allowed to pivot in their mountings to provide alignment along the length of their contact surfaces. The curved ring specimens were $19 \mathrm{~mm}$ sections cut from a manufactured piston ring and their holders permitted alignment with the cylinder liner as well.

The reciprocating motion of $108 \mathrm{~mm}$ stroke was provided by attaching the ring specimen holder to one piston of a motored four cylinder engine. The top of the engine also provided the solid base for supporting the specimen holders and loading mechanism, Figure 2. A $5.2 \mathrm{~kW}$ electric motor with an eddy-current clutch to provide a continuously variable speed was used to drive the engine. While the engine was capable of operation to $2200 \mathrm{rpm}$, balancing problems limited the upper speed to $1500 \mathrm{rpm}$. The specimen holder connecting rod was instrumented to measure dynamic loads to enable measuring the friction forces at the ring/cylinder interface. The electric current needed to actuate the eddy current clutch was found to correlate linearly with the dynamic force measurements, which provided a simple and reliable means for monitoring the dynamic frictional forces.

Temperature and atmospheric control was provided by an insulated stainless steel chamber around the specimens and heaters within the enclosure. The specimen chamber was designed for operation to $650 \mathrm{C}$. A $4.5 \mathrm{~kW}$ single cylinder diesel engine was used to provide exhaust gases to the enclosure to reproduce the actual diesel cylinder environment. The exhaust gas stream was passed through a heating chamber before introduction to the test chamber to heat it to the test temperature. While the capabilities of the apparatus are described above, the standard test conditions used in this study are given in Table 1.

\section{Experimental procedures}

\section{Material Selection}

Table 2 summarizes the materials used in the most recent phase of this study. Most of the materials evaluated were selected by Caterpillar, Inc. and Cummins Engine Co. Candidate materials were first screened by these companies on bench wear testers (such as pin-on-disk, Hohman A-6, and Cameron Plint TE77). Those that produced encouraging wear results were evaluated further in this study. For the radioactive ion implantation, $\mathrm{Si}_{3} \mathrm{~N}_{4}$ was chosen as the material to be implanted because of its wear resistance and its popularity as a direct ceramic replacement for many metallic engine components. 


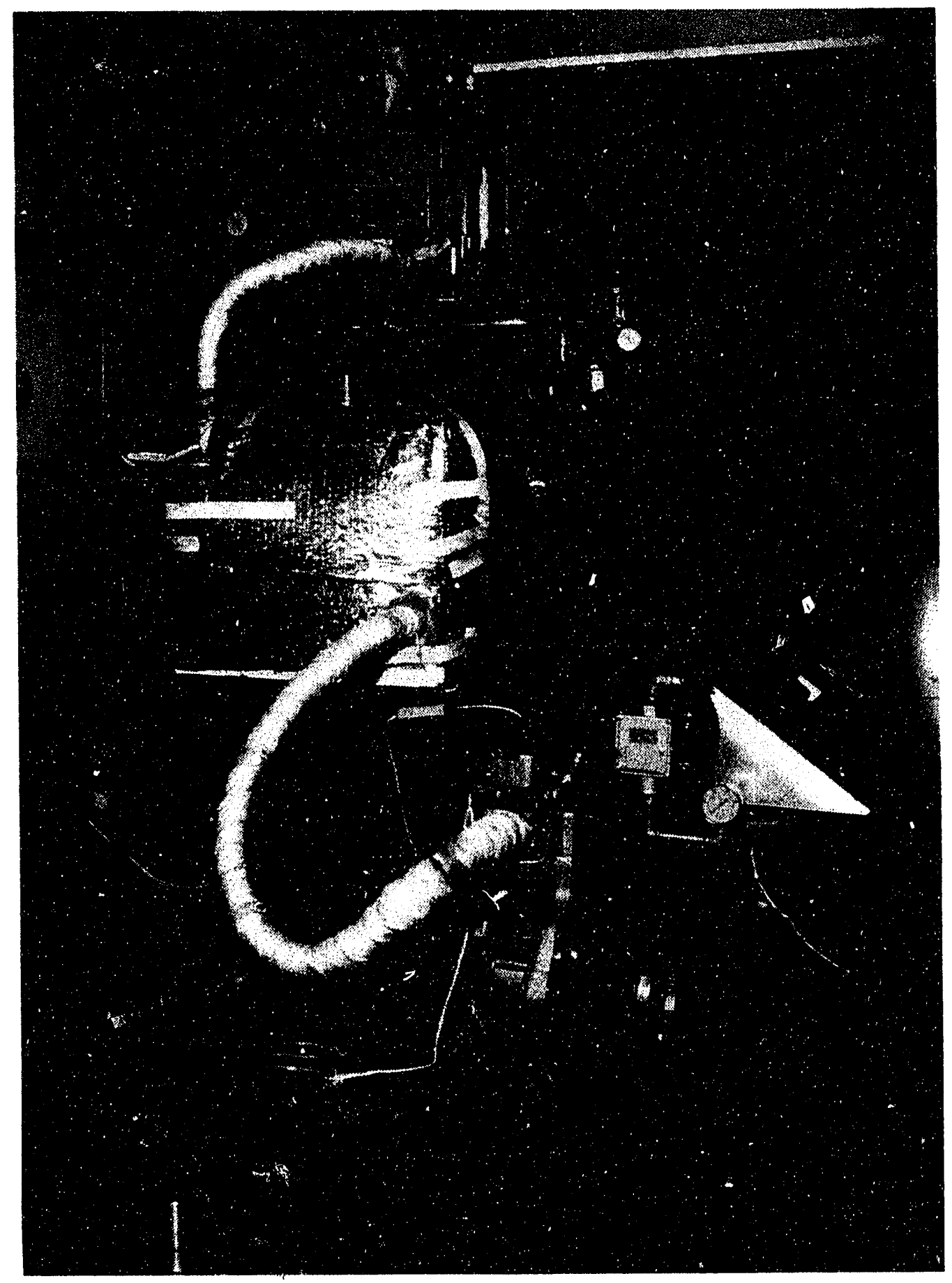

Figure 2. Photograph of wear apparatus. 
Table 1. Summary of Testing Conditions.

\begin{tabular}{|l|l|}
\hline Sliding Contact: & Initial "line" contact becoming flat-on-flat \\
\hline "Cylinder" Specimens & $13 \times 32 \times 127 \mathrm{~mm}$ \\
\hline "Ring" Specimens & $\begin{array}{l}3.2 \times 19 \times 19 \mathrm{~mm} \text { or 19-mm section of } \\
\text { piston ring }\end{array}$ \\
\hline "Ring" Crown Radius & $32 \mathrm{~mm}$ or as supplied \\
\hline Motion & Reciprocating, 108-mm stroke \\
\hline Reciprocating Sped & $500 \mathrm{rpm}$ \\
\hline Average Specimen Speed & $1.8 \mathrm{~m} / \mathrm{s}$ \\
\hline Ring Loading & $10.6 \mathrm{~N} / \mathrm{mm}$ for coatings \\
\hline Temperature & $2.3 \mathrm{~N} / \mathrm{mm}$ for monolithic ceramics \\
\hline Atmosphcre & R.T. or 260 C \\
\hline Measurements & Diesel exhaust \\
\hline
\end{tabular}

Table 2. Materials used in this study.

\begin{tabular}{|l|l|l|}
\hline \multicolumn{1}{|c|}{ Material } & \multicolumn{1}{c|}{ Specimen } & \multicolumn{1}{c|}{ Supplier } \\
\hline $\begin{array}{l}\text { High Carbon } \\
\text { Iron Molybdenum }\end{array}$ & liner & Caterpillar \\
\hline Chromia-Silica & ring & Caterpillar \\
\hline $\begin{array}{l}\text { Molybdenum-Chrome } \\
\text { Carbide }\end{array}$ & ring & Caterpillar \\
\hline Chrome Oxide (SCA) & liner & Kaman Science/Caterpillar \\
\hline Aluminum Titanate & ring & Caterpillar \\
\hline $\begin{array}{l}\text { HVOF Chrome Carbide- } \\
\text { Nickel Chrome }\end{array}$ & ring & Turbine metal Technology \\
\hline $\begin{array}{l}\text { HVOF Tungsten Carbide- } \\
\text { Cobalt }\end{array}$ & ring & Turbine metal Technology \\
\hline APS Chrome Oxide & ring & B.I.R.L. \\
\hline H13 Tool Steel & liner & Cummins \\
\hline
\end{tabular}




\section{Modifications for Testing Curved Specimens}

Some of the materials provided by Caterpillar were supplied in the form of piston rings and cylinder liners. While the experimental rig could not be easily modified to run complete rings and liners, testing curved sections cut from them was possible. Evaluating actual piston rings and cylinder liners when possible was preferred over specially prepared "flat" rings and liners because of manufacturing variability. By using sections of rings and liners, one is assured that the coating or material composition, coating process, substrate material, surface finish and all of the other manufacturing variables of the wear specimens is identical to those of the manufactured components.

To run curved wear specimens some minor modifications to the wear test rig were needed. Spacers were placed behind the thinner curved liner specimens so that the clamping mechanism did not have to be changed, and special ring specimen holders were fabricated from a piston as shown in Figure 3. The top compression rings supplied for testing had a "keystone" cross section. This shape allowed the ring section to fit snugly in the groove of the piston section without any additional clamping measures. The outer radius of the piston section, however, was ground back so the crown of the piston ring extended past it when it was fully seated in the ring groove.

The only problem encountered when setting up to run curved specimens was that the curvature of the ring and cylinder segments did not match. Unconstrained by a circular cylinder liner, the ring segments assumed the larger curvature of a ring in its relaxed state. Even sections cut from near the ring gap did not exactly match the liner curvature indicating that perhaps the cylinder liner had relaxed somewhat itself when cut into sections. In an attempt to bend the ring segments to the proper curvature, radial relief cuts were made in the back of them to minimize the tensile stress produced during bending. When the cuts had been made, the curvature matched up very well without having to try to bend (and probably break) the rings. Apparently the internal stresses were such that the ring took on a smaller radius of curvature when the relief slots were cut.

\section{Material Evaluation}

The standard operating conditio... for this study were presented in Table 1. The test sequence started with a 1 hour run at room temperature for an initial break-in period. Ring profile wear measurements were made using a Talysurf 6 surface profilometer before and after the break-in test to see how wide the worn "flat" was across the crowned face of the ring specimens. The specimens were then reassembled and run for at least one 4-hour period at $260 \mathrm{C}$. Specimens showing particularly low wear after the second profile measurement were run for one or more additional 4-hour periods to establish the long-term wear rates, with the wear measurement repeated between each of the subsequent test intervals. In most cases the wear rates after the second 4-hour period were not significantly 


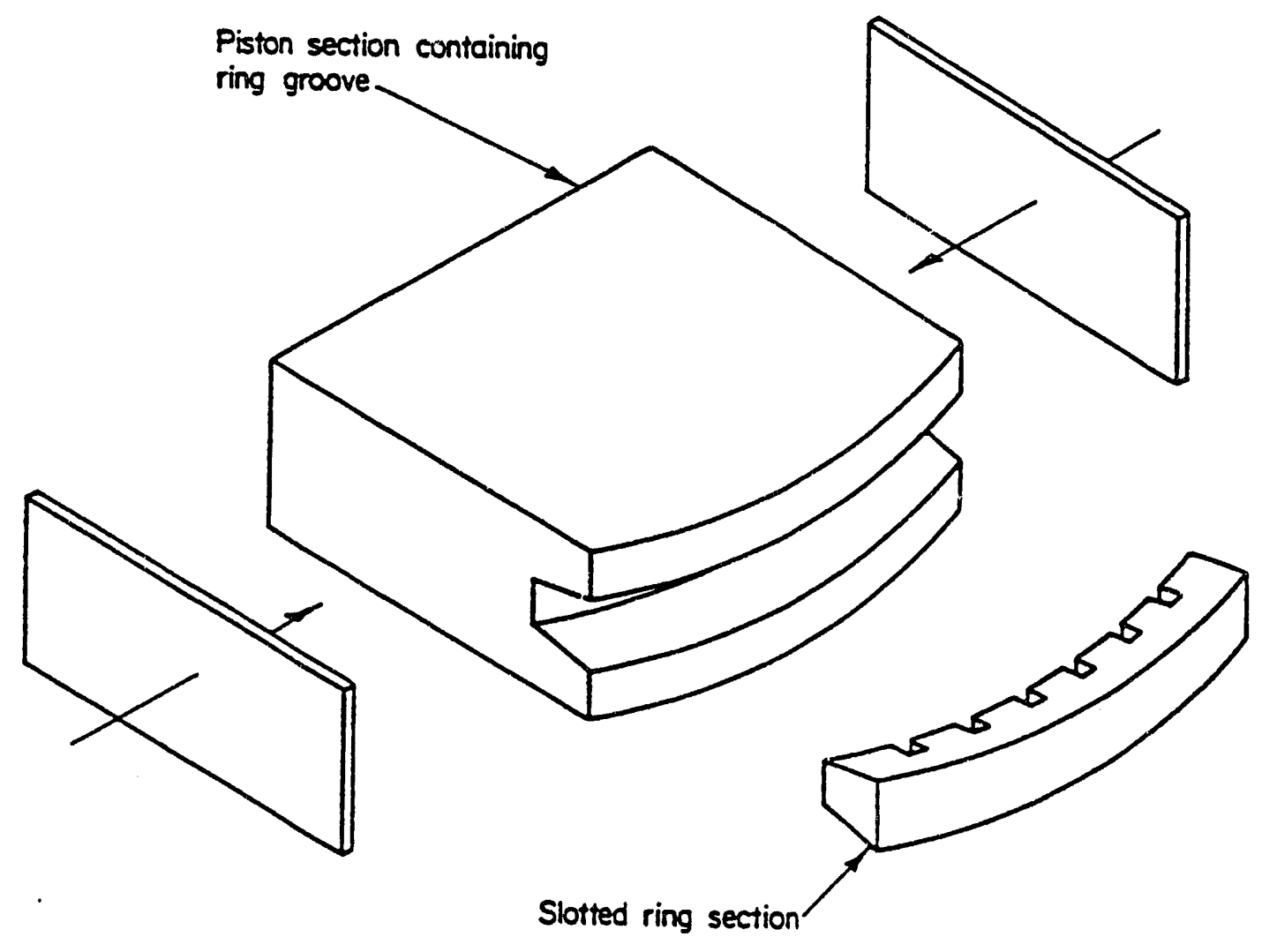

Figure 3. Curved ring specimen holder. 
different from those of the first 4-hour interval, which indicated that break-in had occurred and the contacts had reached an equilibrium wear condition.

\section{Results and Discussion}

Ring specimen wear is presented in terms of a wear factor to permit a direct comparison for the various material combinations obtained at different load and speed combinations. The wear of the ring specimens alone was used as the measure of relative performance since the majority of the wear occurred on the ring specimens. It was also difficult to get accurate liner wear measurements after only a few hours of running. The average ring wear factor given in the results is the average of all of the tests portions conducted with each material combination. When multiple 4-hour runs were conducted, wear factors from all test portions were included in the average. The wear factors were calculated as follows:

$$
k=\frac{V}{L x} \mathrm{~mm}^{3} / \mathrm{Nm},
$$

where:

$$
\begin{aligned}
& \mathbf{k}=\text { wear factor } \\
& \mathbf{V}=\text { wear volume }, \mathrm{mm}^{3} \\
& \mathrm{~L}=\text { applied load, } \mathrm{N} \\
& \mathbf{X}=\text { sliding distance }, \mathrm{m}
\end{aligned}
$$

Values of the wear factor can range from $10^{-3}$ for severe unlubricated wear to $10^{-9}$ or lower for the extremely low wear rates experienced under conditions of full hydrodynamic lubrication.

\section{Baseline Wear Goal}

The first bar in Figure 4 represents the calculated wear factor of a conventional electroplated chrome piston ring running against a cast iron liner in an over-the-road diesel truck engine. A wear factor of $3 \times 10^{-10} \mathrm{~N} / \mathrm{mm}^{3}$ was calculated assuming an average engine speed of 2000 revolutions per minute, $483,000 \mathrm{~km}$ between overhaul, an average unit ring loading of $17.5 \mathrm{~N} / \mathrm{mm}$, and $0.25 \mathrm{~mm}$ depth of chrome worm from the ring.

When the same materials were tested in the experimental apparatus, an average wear factor of $3 \times 10^{-9} \mathrm{~N} / \mathrm{mm}^{3}$ was measured as represented by the second bar in Figure 4. While this experimental wear factor is an order of magnitude higher than the predicted factor based on field experience with the 


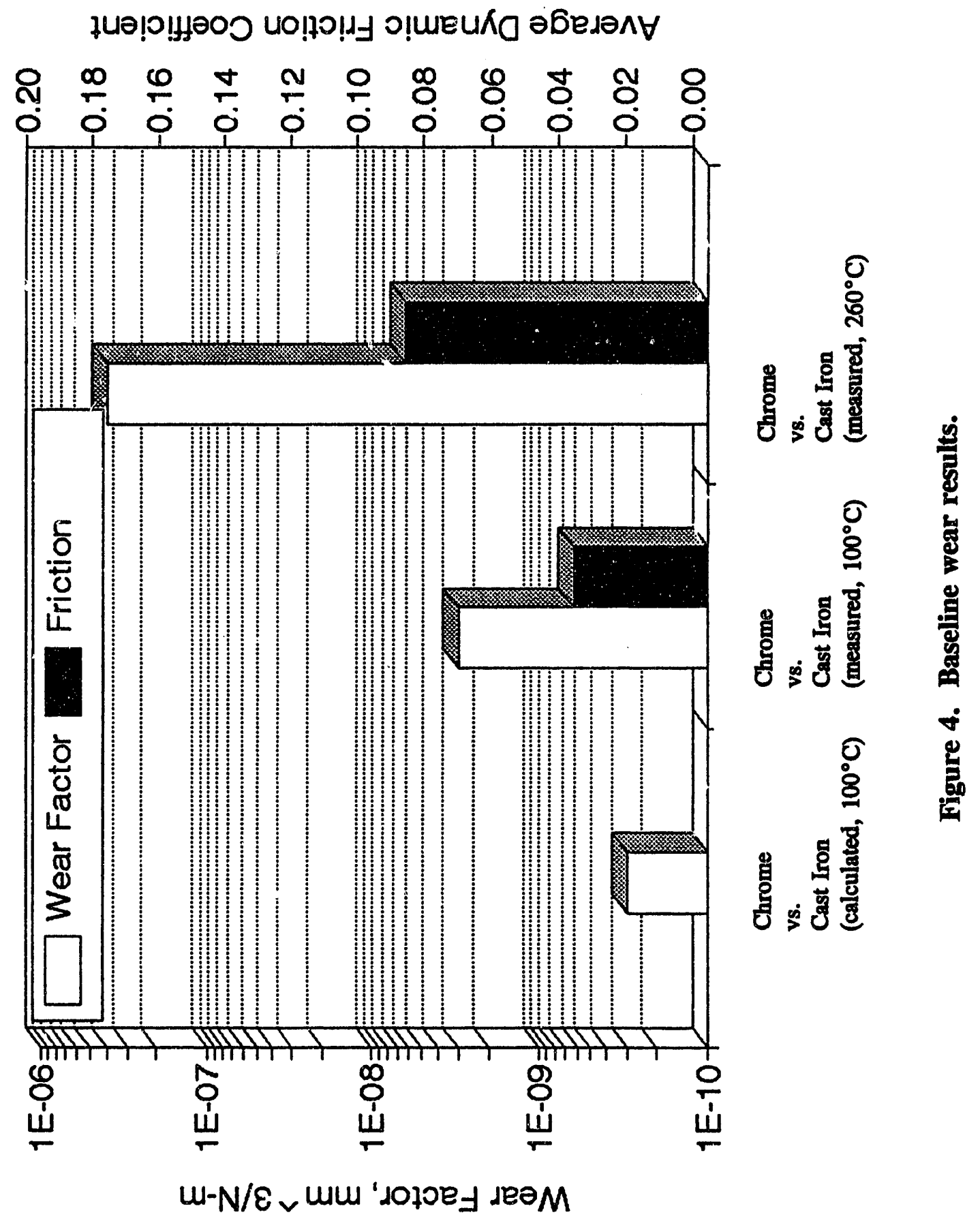


same materials, slightly different test conditions and relatively high experimental error with these kinds of wear tests help explain the difference. The reason lower levels of ring loading were used in the experimental testing than in the prediction model was because the rig was run at a lower reciprocating speed to minimize vibration. The lower reciprocating speid made it difficult to produce elastohydrodynamic lubrication under equivalent loads, so the ring load was reduced to compensate. Because all of the subsequent tests were to be tested under the same experimental conditions, the experimental wear factor of $3 \times 10^{-9} \mathrm{~mm}^{3} / \mathrm{N}-\mathrm{m}$ was chosen for the baseline goal. If a wear factor of $3 \times 10^{-9} \mathrm{~mm}^{3} / \mathrm{N}-\mathrm{m}$ can be obtained with advanced materials at higher temperatures, the wear life of current production engines and low-heat-rejection engines should be similar.

The third bar in Figure 4 demonstrates the reason for conducting this work; at the higher temperatures expected of future low-heat-rejection engines, wear of conventional ring materials increased by more than two orders of magnitude (to $4 \times 10^{-7} \mathrm{~mm}^{3} / \mathrm{N}-\mathrm{m}$ ) over the same materials running at conventional temperatures. Finding advanced replacement materials for metallic engine components may be one way to obtain the low wear rates of today's engines at tomorrow's operating temperatures.

The average dynamic friction coefficient results are also presented in Figure 4. No attempt is made to identify a baseline friction coefficient goal because the fluctuation in the friction measurements typically vary as much as plus-or-minus $\mathbf{4 0}$ percent of the average throughout the test. Work at Cummins has identified a target friction coefficient goal of 0.1 or less for lubricated systems ${ }^{(4)}$. All of the tests reported in this paper meet or exceed this friction requirement. What appears to be a correlation between the average friction coefficient and the log of the wear factor in Figure $?$ is probably coincidental as this behavior is not seen in all of the tests.

\section{Summary of Previous Studies}

To gain an understanding of how attainable this wear performance goal is, some highlights of earlier phases of work are presented here. Figure 5 shows the wear results of the five test material combinations obtained during the first two phases of work. The specific materials and suppliers can be found in earlier publications $^{(5)}$. One of these material combinations exceeds the baseline goal and the other four are within an order of magnitude of it. Again, average dynamic friction coefficients are presented to show the variability of that measurement and are not used to correlate wear performance.

\section{Materials from Diesel Engine Manufacturers}

While the materials tested in earlier phases of the study had excellent friction and wear behavior under high temperature conditions, they may or may not be practical from a materials cost and/or manufacturing standpoint. The purpose of 


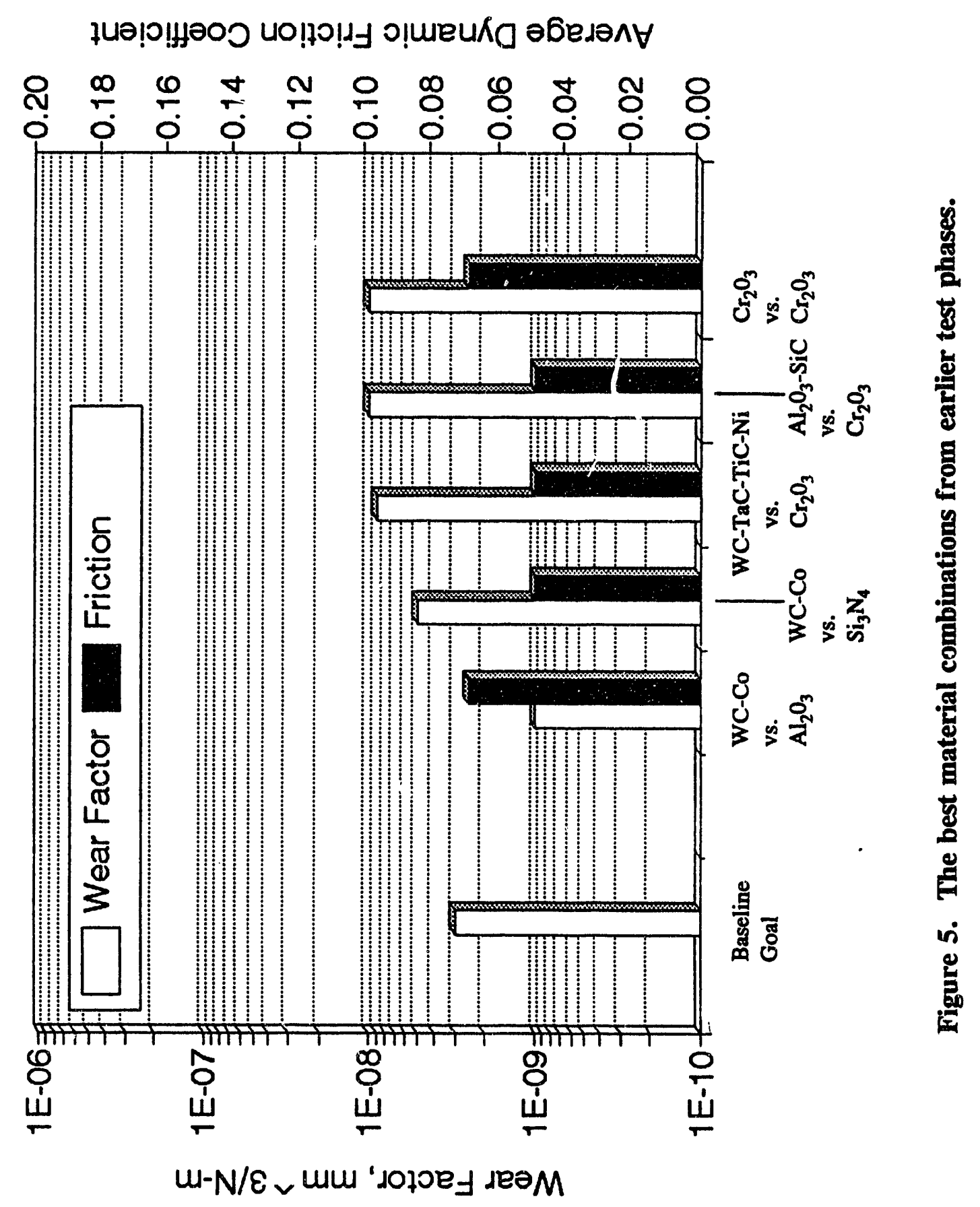


this phase of the work was to test materials that a) diesel engine companies had at least some manufacturing experience with and b) had performed well in the bench tests they conducted. Figure 6 shows the wear and friction results of the materials supplied by Caterpillar for additional testing in the engine simulation rig. Again the baseline wear goal is provided for comparison.

The chromia-silica sliding against high-carbon iron-molybdenum had the lowest wear of the ring coatings supplied by Caterpillar $\left(9 \times 10^{-9} \mathrm{~mm}^{3} / \mathrm{N}-\mathrm{m}\right)$ and was within an order of magnitude of the baseline goal. For such low wear, this coating also had an unusually high average dynamic coefficient of friction throughout the test. The reason for this is not presently known. The molybdenum-chrome carbide and aluminum titanate coated ring specimens were cut from piston rings from an engine with an approximate bore of $125 \mathrm{~mm}$. These coatings showed good, but less encouraging, wear results with average wear factors close to $1 \times 10^{-7} \mathrm{~mm}^{3} / \mathrm{N}-\mathrm{m}$ when tested against chrome oxide (SCA) coatings. Apparently, these coatings were baseline materials in their own right and were intended to be compared with additional materials with enhanced wear performance. The additional materials (in the form of piston rings with a different geometry) were unable to be tested because suitable specimen holders could not be made within the scope of the study. While the curvature of the specimens alone should not affect the wear results significantly, perhaps additional baseline tests should be conducted using specimens cut from chrome plated piston rings and cast iron liners of similar curvature for comparison. These data agree with what Caterpillar achieved in their bench and fired engine tests ${ }^{(6)}$.

The coatings that Cummins Engine Co. found to have promising wear performance in their bench tests were also evaluated. In this series of tests the uncoated cylinder liner specimens were made from hardened H13 tool steel. Similarly, the substrates for the ring coatings were also hardened $\mathrm{H} 13$ tool steel. The ring coatings were high-velocity oxy-fuel (HVOF) coatings of chrome carbide-nickel-chrome, HVOF tungsten carbide-cobalt, and plasma sprayed chrome oxide. Figure 7 shows the friction and wear results of these materials compared with the baseline goal. The most similar bench test data from Cummins is also shown for comparison $(7)$. Average wear factors were similar for all three materials and ranged from $6 \times 10^{-8} \mathrm{~mm}^{3} / \mathrm{N}-\mathrm{m}$ to $2 \times 10^{-7} \mathrm{~mm}^{3} / \mathrm{N}-\mathrm{m}$ in the tests conducted in this study. The relative wear factors of the three materials correspond to the results obtained in bench tests at Cummins, however, the absolute wear factors are about an order of magnitude higher. Different ring specimen substrates and cylinder liner materials used during testing may be one reason for the differences. In the Cummins testing, Type 422 stainless steel ring substrates were used as well as pearlitic grey iron liners. As mentioned earlier, this study used H13 tool steel for both the ring substrates and liners. Similar cobalt-bonded tungsten carbide and the chrome oxide coatings were tested in the earlier test phases (Figure 4) and produced wear results which agree more closely with the Cummins data. 


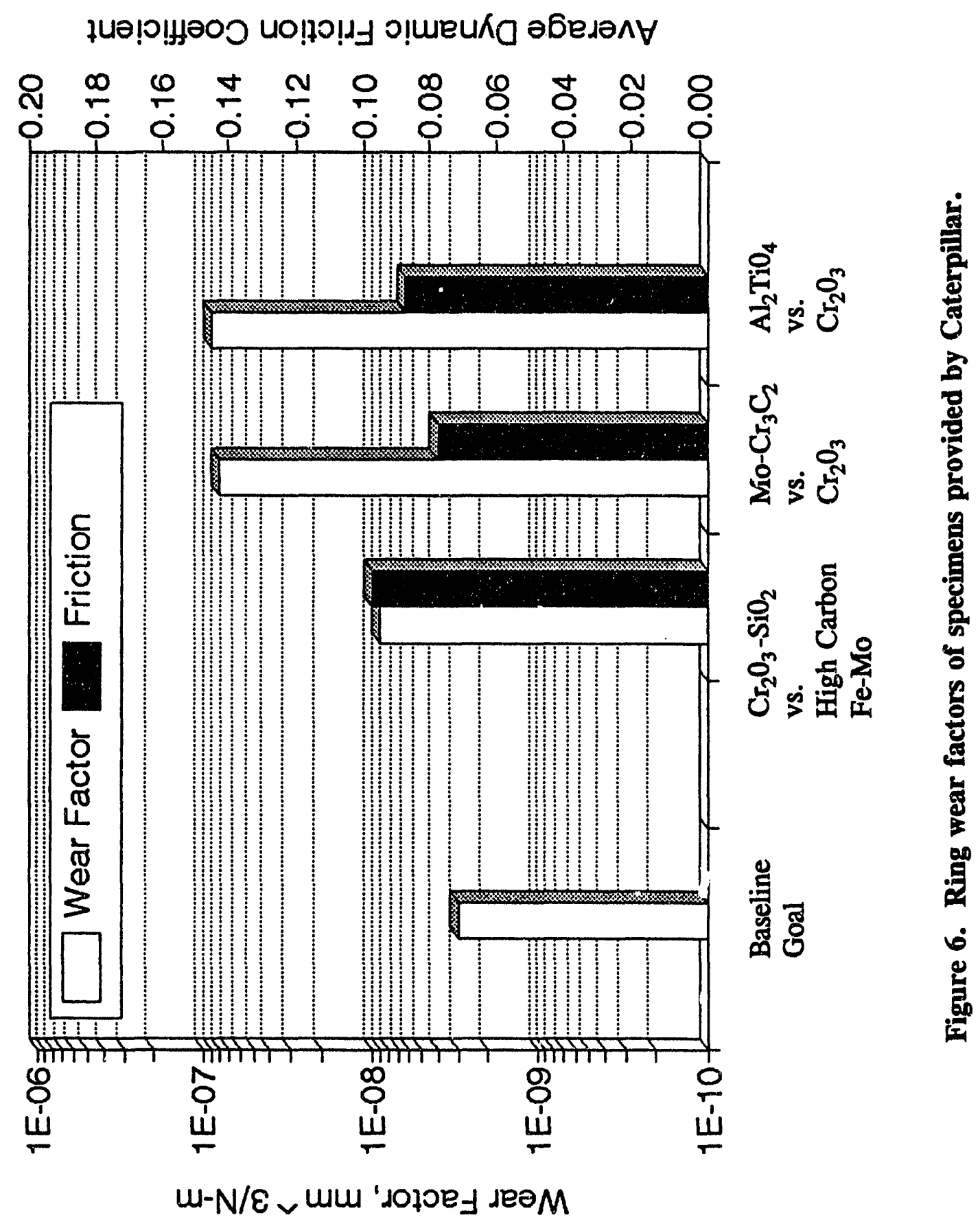




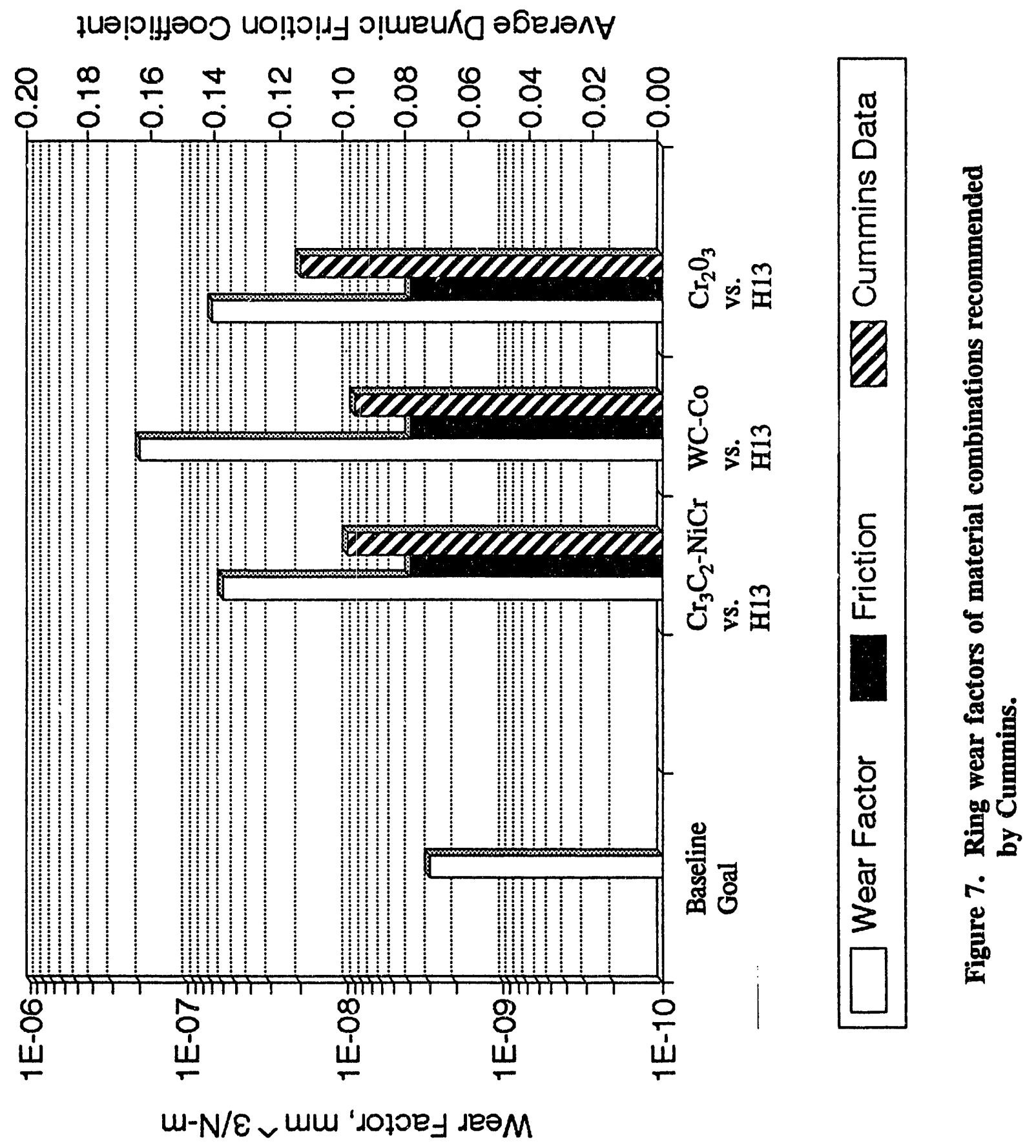


A summary of all of the different wear test results discussed thus far is shown in Figure 8. The material combinations tested during this phase were selected because of their potential for production as much as for wear resistance. For this reason, wear rate may be compromised somewhat for the sake of manufacturing considerations.

\section{Wear of Ion-Implanted Silicon Nitride}

The feasibility of implanting ${ }^{7} \mathrm{Be}$ and ${ }^{22} \mathrm{Na}$ ions in ceramic materials for the purpose of wear studies has been demonstrated by researchers at Michigan State University (M.S.U. $)^{(8,9)}$. The intensity of low-level $\gamma$ radiation emitted from the wear surface of the radioactive-ion-implanted (RII) material can be correlated to the depth of wear. This method is said to be capable of resolving wear as low as $50 \mathrm{~nm}$.

Wear tests were conducted to determine if the implantation itself would influence the wear rate of the material. M.S.U. supplied a number of control silicon nitride ring specimen: as well as some that were implanted with six doses of $10^{12}$ particles of ${ }^{20} \mathrm{Ne}$. This non-radioactive ion is similar in size to ${ }^{22} \mathrm{Na}$ and should produce similar implantation damage. The dosage was 2 to 3 orders of magnitude higher than required for using ion-implantation as a wear diagnostic tool so that any damage would be intensified. Each of the six doses was implanted to different depths, which ranged from less than $5 \mu \mathrm{m}$ to about $10 \mu \mathrm{m}$. Any damage, characterized by an increase in wear rate, would be located in the region between these depthis.

Tests were run with ten mating pairs of silicon nitride rings and chrome oxide-coated cylinder liners. Five of the silicon nitride rings were control specimens and five were implanted with ${ }^{20} \mathrm{Ne}$. Each test consisted of three portions, a one-hour break-in followed by two iwo-hour runs. Ring wear measurements were taken before and after each of the two-hour test portions to obtain an average wear factor for each test portion specimen and to ensure that the wear was confined to the first $10 \mu \mathrm{m}$. The two wear factors for each ring specimen were then averaged to get a single wear factor for each ring specimen.

The results are presented in Figure 9. All ten of the average wear factors measured are within an order of magnitude of each other (between $8 \times 10^{-9}$ and 4 $\left.\mathrm{X} 10^{-8} \mathrm{~mm}^{3} / \mathrm{N}-\mathrm{m}\right)$, which is typical for these wear tests. The average wear factor for all of the control specimens compared with all of the implanted specimens also indicates that there is no significant difference in the wear rate performance of the control and implanted specimens. Since these ions are similar in size to ${ }^{22} \mathrm{Na}$ ions, it is expected that the effect of implanting silicon nitride with ${ }^{22} \mathrm{Na}$ would also be negligible. 


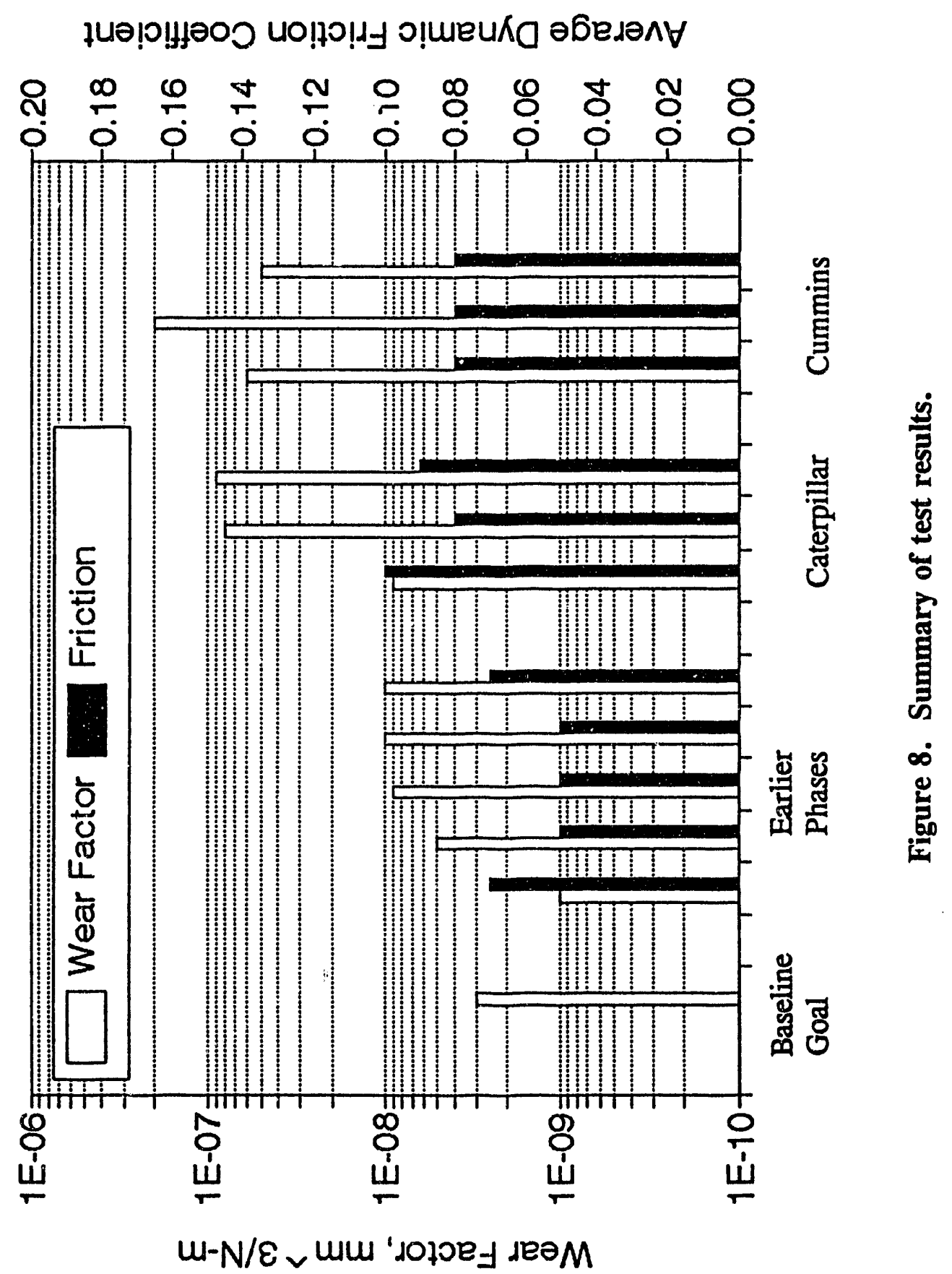



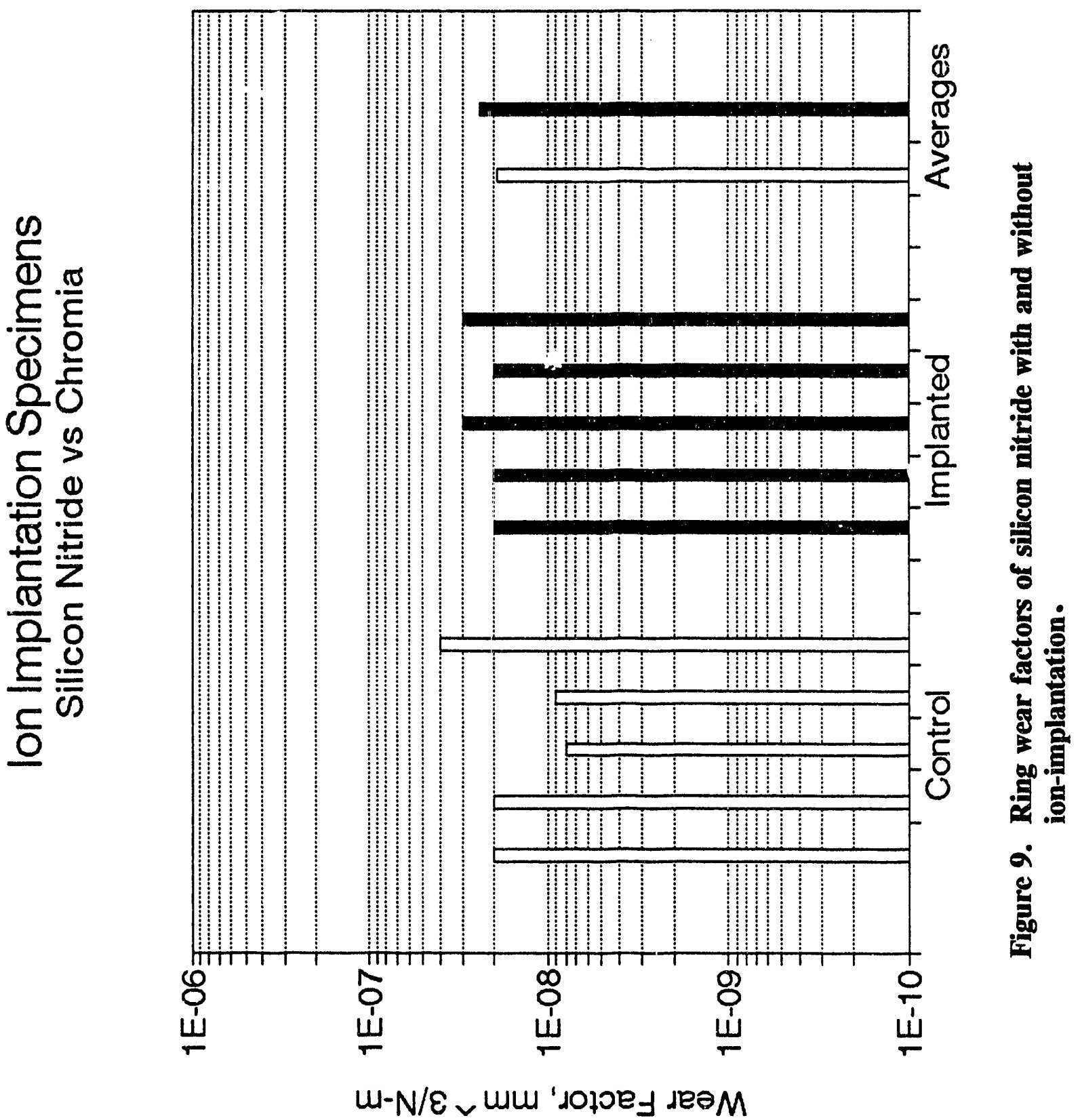


\section{Conclusions}

Diesel engine manufacturers supplied or recommended material combinations for this study based primarily on the wear performance achieved during screening tests. Selection criteria for the materials, however, also included practicality issues related to manufacturing. Additional testing of these material combinations was performed in this study on an experimental wear apparatus that simulates the piston ring/cylinder liner interface. The results showed that the wear performance of these materials was generally lower than both the baseline wear goal as well as some of the material combinations tested in previous phases of this program. Perhaps there currently is a compromise between ultimate wear performance and manufacturability. Continued testing of manufactured engine components as opposed to specially prepared specimens should help reduce or eliminate this compromise. Finally, Radioactive Ion Implantation was not shown to affect the wear performance of monolithic silicon nitride adversely. The in situ mnnitoring of engine wear using this safe and extremely accurate method could also increase the practicality of fired engine tests since the engine would not have to be periodically disassembled to measure wear. 


\section{References}

1. P.A. Gaydos, and K.F. Dufrane, "Lubrication of Ceramics in Ring/Cylinder Applications", SAE Paper 890888, 1989.

2. K.F. Dufrane, W.A. Glaeser, and A.R. Rosenfield, "Studies of Dynamic Contact of Ceramics and Alloys for Advanced Heat Engines", ORNL/Sub/84-00216/1, 1988.

3. P.A. Gaydos, and K.F. Dufrane, "Studies of Dynamic Contac: of Ceramics and Alloys for Advanced Heat Engines", ORNL/Sub/84-0021/1, 1992.

4. M.G.S. Naylor, "Development of Wear-Resistant Ceramic Coatings for Diesel Engine Components", ORNL/Sub/87-SA581/1, 1992.

5. P.A. Gaydos, and K.F. Dufrane, "Studies of Dynamic Contact of Ceramics and Alloys for Advanced Heat Engines", ORNL/Sub/84-0021/1, 1992.

6. M.H. Haselkorn, Caterpillar Inc., personal communication, August 4, 1992.

7. M.G.S. Naylor, "Development of Wear-Resistant Ceramic Coatings for Diesel Engine Components", ORNL/Sub/87-SA581/1, 1992.

8. H.J. Schock, et al., "Production and Implantation of Ions for Wear Studies and Monitoring of Machining Processes", MSUERL Report 91-3, 1991.

9. M.L. Mallory, et al., "Tribology Studies: ${ }^{7}$ Be Implantation in a Ceramic Sample by means of a Fragmented High-Energy ${ }^{14} \mathrm{~N}$ Beam", MSUCL-658, 1988. 
ORNL/Sub/84-00215/2

INTERNAL DISTRIBUTION

Central Research Library (2)

Document Reference Section

Laboratory Records Department (2)

Laboratory Records, ORNL RC

ORNL Patent Section

M\&C Records Office (3)

L. F. Allard, Jr.

L. D. Armstrong

P. F. Becher

R. F. Bernal

T. M. Besmann

P. J. Blau

A. Bleier

E. E. Bloom

K. W. Boling

R. A. Bradley

C. R. Brinkman

V. R. Bullington

R. S. Carlsmith

P. T. Carlson

G. M. Caton

S. J. Chang

R. H. Cooper, Jr.

B. L. Cox

D. F. Craig

S. A. David

J. H. DeVan

J. L. Ding

M. K. Ferber

F. M. Foust

C. R. Hubbard

M. A. Janney

M. G. Jenkins

D. R. Johnson

D. Joslin

R. R. Judkins

M. A. Karnitz

M. R. Kass

B. L. P. Keyes

H. D. Kimrey, Jr.

K. C. Liu

E. L. Long, Jr.

W. D. Manly

R. W. McClung

D. J. McGuire

J. R. Merriman

T. A. Nolan

A. E. Pasto

J. L. Rich

J M Robbins

M. L. Santella

A. C. Schaffhauser

S. Scott

G. M. Slaughter

E. J. Soderstrom

D. P. Stinton

R. W. Swindeman

V. J. Tennery

T. N. Tiegs

J. R. Weir, Jr.

W. Fulkerson

B. H. West

R. L. Graves

F. W. Wiffen

D. L. Greene

S. G. Winslow

M. H. Harris

J. M. Wyrick

E. E. Hoffman

C. S. Yust 


\section{EXTERNAL DISTRIBUTION}

Pioneering Research Information Center

E. I. DuPond de Nemours \& Co., Inc.

Experimenta! Station

P. O. Box 80302

Wilmington, DE 19880-0302

James H. Adair

University of Florida

Materials Science and Engineering

317 MAE Bldg.

Gainesville, FL 32611-2066

Donald F. Adams

University of Wyoming

Mechanical Engineering Department

P. O. Box 3295

Laramie, WY 82071

Jalees Ahmad

AdTech Systems Research, Inc.

1342 North Fairfield Road

Dayton, OH 45432-2698

Yoshio Akimune

NISSAN Motor Co., Ltd.

Materials Research Laboratory

1 Natsushima-Cho

Yokosuka 237

JAPAN AIR MAIL

Mufit Akinc

Iowa State University

322 Spedding Hall

Ames, IA 50011

Ilhan A. Aksay

Princeton University

Department of Chemical

Engineering \& PMI

A313 Engineering Quandrangle

Princeton, NJ 08544-5263
R. G. Alexander

BASE, 26 Malvern Close

Kettering Northants NN16 AJP

UNITED KINGDOM AIR MAIL

Richard L. Allor

Ford Motor Company

Material Systems

Reliability Department

20000 Rotunda Drive

P.O. Box 2053, Room S-2031

Dearborn, MI 48121-2053

Joseph E. Amaral

Instron Corporation

Corporate Engineering Office

100 Royale Street

Canton, MA 02021

Edward M. Anderson

Aluminum Company of America

North American Industrial

Chemicals Division

P.O. Box 300

Bauxite, AR 72011

Norman C. Anderson

Ceradyne, Inc.

Ceramic-to-Metal Division

3169 Redhill Avenue

Costa Mesa, CA 92626

Don Anson

Battelle Columbus Laboratories

Thermal Power Systems

505 King Avenue

Columbus, $\mathrm{OH}$ 43201-2693 
Thomas Arbanas

G.B.C. Materials Corporation

580 Monastery Drive

Latrobe, PA 15650-2698

Frank Armatis

3M Company

3M Center

Building 60-1N-01

St. Paul, MN 55144-1000

Everett B. Arnold

Detroit Diesel Corporation

Mechanical Systems Technology

13400 Outer Drive, West

Detroit, MI 48239-4001

Richard M. Arons

PA Consulting Group

279 Princeton Road

Hightstown, NJ 08550

Bertil Aronsson

Sandvik AB

S-12680

Stockholm Lerkrogsvagen 19

SWEDEN AIR MAIL

Dennis Assanis

University of Illinois

Department of Mechanical Engineering

1206 W. Green Street

Urbana, IL 61801

William H. Atwell

Dow Corning Corporation

3901 South Saginaw Road

MS:540

Midland, MI 48686-0995

V. S. Avva

North Carolina A\&T State University

Department of Mechanical Engineering

Greensboro, NC 27411
Patrick Badgley

Adiabatics, Inc.

3385 Commerce Drive

Columbus, IN 47201

Sunggi Baik

Pohang Institute of Science \& Technology

Department of Materials Science and Engineering

P.O. Box 125

Pohang 790-600

KOREA AIR MAIL

John M. Bailey

Caterpillar, Inc.

Technical Center, Building L

P.O. Box 1875

Peoria, IL 61656-1875

Bob Baker

Ceradyne, Inc.

3169 Redhill Avenue

Costa Mesa, CA 92626

Frank Baker

Aluminum Company of America

Alcoa Technical Center

Alcoa Center, PA 15069

J. G. Baldoni

GTE Laboratories Inc.

40 Sylvan Road

Waltham, MA 02254

Clifford P. Ballard

Allied-Signal, Inc.

Ceramics Program

P.O. Box 1021

Morristown, NJ 07962-1021

B. P. Bandyopadhyay

Toyohashi University of Technology

School of Production Systems Engineering

Tempaku-Cho Toyohashi 440

JAPAN AIR MAIL 
P. M. Barnard

Ruston Gas Turbines Limited Metallurgical Laboratory

P. O. Box 1

Lincoln LN2 5DJ

ENGLAND AIR MAIL

Harold N. Barr

Hittman Corporation

9190 Red Branch Rc ad

Columbia, MD 21045

Renald D. Bartoe

Vesuvius McDaiel

510 Ninth Avenue

Box 560

Beaver Falls, PA $\$ 5010-01560$

David L. Eaty

Babcock \& Wilecu-LRC

P.O. Box 11165

Lynchburg, VA 24506-1165

Donald F. Baxter, Jr.

ASM International

Advanced Materials and Processes

Materials Park, OH 44073.0002

M. Brad Beardsley

Caterpillar, Inc.

Advanced Materials Technology

Technical Center Bldg. E

P.O. Box 1875

Peoria, M 61656-18'/5

John C. Bell

Shell Research Limited

Thornton Research Centre

P.O. Box 1, Chester, Ch1 3SH

ENGLAND AIR MAIL

Albert H. Bell, III

General Motors Technical Center 30200 Mound Road

Engineering Building/W3 Turbine

Warren, MI 48090-9010

\author{
M. Bentele \\ Xamag, Inc. \\ 259 Melville Avenue \\ Fairfield, CT 06430 \\ Larry D. Bentsen \\ BF Goodrich Company \\ R\&D Center \\ 9921 Brecksville Road \\ Brecksville, OH 44141 \\ Joseph C. Bentz \\ ENCERATEC \\ 2525 Sandcrest Drive \\ Columbus, IN 47203
}

Louis Beregszazi

Defiance Precision Products

P.O. Drawer 428

Defiance, OH 43512

Tom Bernecki

Northwestern University

BIRL

1801 Maple Avenue

Evanston, IL 60201-3135

Charles F. Bersch

Institute for Defense Analyses 1801 North Beauregard Street

Alexandiria, VA 22311

Ram Bhatt

NASA Lewis Research Center

21000 Brookpark Road

Cleveland, $\mathrm{OH} 44135$

Deane I. Biehler

Caterpillar, Inc.

Engineering and Research Materials Technical Center, Building E

P.O. Box 1875

Peoria, IL 61656-1875 
John. W. Bjerklie

Consolidated Natural Gas

Service Co., Inc.

Research Department

CNG Tower

Pittsburgh, PA 15222-3199

William D. Bjorndahl

TRW, Inc.

One Space Park

Building 01, Room 2040

Redondo Beach, CA 90278

Keith A. Blakely

Advanced Refractory Technologies, Inc.

699 Hertel Avenue

Buffalo, NY 14207

Edward G. Blanchard

Netzsch Inc.

119 Pickering Way

Exton, PA 19341

Bruce Boardman

Deere and Company Technical Center 3300 River Drive

Moline, IL 61265

Russell Bockstedt

Hoechst Celanese Corporation

150 JFK Parkway

Short Hills, NJ 07078

M. Boehmer

DLR German Aerospace Research

Establishment

Postfach 906058

D-5000 Koln 90

GERMANY AIR MAIL

Lawrence P. Boesch

EER Systems Corp.

1593 Spring Hill Road

Vienna, VA 22182-2239
Donald H. Boone

Boone \& Associates

2412 Cascade Drive

Walnut Creek, CA 94598-4313

Tom Booth

Allied-Signal Aerospace Company

AiResearch Los Angeles Division

2525 West 190th Street

Torrance, CA $90509-2960$

Tibor Bornemisza

Sundstrand Power Systems

4400 Ruffin Road

San Diego, CA 92186-5757

J.A.M. Boulet

University of Tenressee

Department of Engineering

Science and Mechanics

310 Perkins Hall

Knoxville, TN 37996-2030

H. Kent Bowen

Massachusetts Institute of

Technology

77 Massachusetts Avenue

Room E40-434

Cambridge, MA 02139

Leslie J. Bowen

Materials Systems

53 Hillcrest Road

Concord, MA 01742

Steven C. Boyce

Air Force Office of Scientific

Research

AFOSR/NA Bldg. 410

Bolling AFB DC 20332-6448

Steve Bradley

UOP Research Center

50 East Algonquin Road

Des Plaines, IL 60017-6187 
Michael C. Brands

Cummins Engine Company, Inc.

P.O. Box 3005

Mail Code 50179

Columbus, IN 47201

Raymond J. Bratton

Westinghouse Science and

Technology Center

1310 Beulah Road

Pittsburgh, PA 15235

John J. Brennan

United Technologies Corporation

Research Center

Silver Lane, MS:24

East Hartford, CT 06108

Jeff D. Bright

Ceramatec, Inc.

2425 South 900 West

Salt Lake City, UT 84108

Terrence K. Brog

Coors Ceramics Company

Corporate Development and Technology

4545 McIntyre Street

Golden, CO 80403

Gunnar Broman

317 Fairlane Drive

Spartanburg, SC 29302

Al Brown

High-Tech Materials Alert

P.O. Box 882

Dayton, NJ 08810

Jesse Brown

Virginia Polytechnic Institute and State University

Center for Advanced Ceramic Materials

Blacksburg, VA 24061-0256
Sherman D. Brown

University of Illinois

Materials Science and

Engineering Department

105 South Goodwin Avenue

204 Ceramics Building

Urbana, IL 61801

S. L. Bruner

Ceramatec, Inc.

2425 South 900 West

Salt Lake City, UT 84119

Adolfo Brusaferro

Keramont Corporation

4231 South Fremont Avenue

Tucson, AZ 85714

Walter Bryzik

U.S. Army Tank Automotive

Command

R\&D Center

Propulsion Systems Division

Warren, MI 48397-5000

S. T. Buljan

GTE Laboratories, Inc.

40 Sylvan Road

Waltham, MA 02254

S. J. Burden

GTE Valenite

1711 Thunderbird

Troy, MI 48084

Curt V. Burkland

AMERCOM, Inc.

8928 Fullbright Avenue

Chatsworth, CA 91311

Bill Bustamante

AMERCOM, Inc.

8928 Fullbright Street

Chatsworth, CA 91311 
Oral Buyukozturk

Massachusetts Institute of Technology

77 Massachusetts Avenue

Room 1-280

Cambridge, MA 02139

David A. Caillet

Ethyl Corporation

451 Florida Street

Baton Rouge, LA 70801

Frederick J. Calnan

Heany Industries, Inc.

249 Briarwood Lane

P.O. Box 38

Scottsville, NY 14546

Roger Cannon

Rutgers University

Ceramics Department

P.O. Box 909

Piscataway, NJ 08855-0909

Scott Cannon

P.O. Box 567254

Atlanta, GA 30356

Harry W. Carpenter

19945 Acre Street

Northridge, CA 91324

David Carruthers

Kyocera Industrial Ceramics Company

P.O. Box 2279

Vancouver, WA 98668-2279

Calvin H. Carter, Jr.

Cree Research, Inc.

2810 Meridian Parkway

Durham, NC 27713

J. David Casey

35 Atlantis Street

West Roxbury, MA 02132
Jere G. Castor

J. C. Enterprise

5078 North 83rd Street

Scottsdale, AZ 85250

Jame: D. Cawley

Case Western Reserve University

Materials Science and

Engineering Department

Cleveland, OH 44106

Thomas C. Chadwick

Den-Mat Corporation

P.O. Box 1729

Santa Maria, CA 93456

Ronald H. Chand

Chand Kare Technical Ceramics

2 Coppage Drive

Worcester, MA 01603

Robert E. Chaney

EG\&G Idaho, Inc.

Idaho National Engineering

Laboratory

P.O. Box 1625

Idaho Falls, ID 83415-3525

Frank C. Chang

U.S. Army Materials

Technology Laboratory

AMTL-EMM

405 Arsenal Street

Watertown, MA 02172

Robert M. Chapman

Allied-Signal Aerospace Company

1001 Pennsylvania Avenue, N.W.

Suite 700 South

Washington, DC 20004

William Chapman

Williams International Corporation 2280 West Maple Road

Walled Lake, MI 48390-0200 
Charlie Chen

LECO Corporation

P.O. Box 211688

Alimista, GA 30917

Frank Childs

EG\&G Idaho, Inc.

Idaho National Engineering Laboratory

P.O. Box 1625

Idaho Falls, ID 83415-3527

William J. Chmura

Torrington Company

59 Field Street

Torrington, CT 06790-4942

Tsu-Wei Chou

University of Delaware

Center for Composite Materials

201 Spencer Laboratory

Newark, DE 19716

R. J. Christopher

Ricardo Consulting Engineers

Bridge Works

Shoreham-By-Sea West Sussex

BN43 5FG

ENGLAND AIR MAIL

Joel P. Clark

Massachusetts Institute of Technology

Room 8-409

Cambridge, MA 02139

Giorgio Clarotti

Commission of the European

Communities

DGXII-C3, M075, 1-53;

200 Rue de la Loi

B-1049 Brussels

BELGIUM AIR MAIL

W. J. Clegg

ICI Advanced Materials

P.O. Box 11

The Heath, Runcorn Cheshire

WA7 4QE

ENGLAND AIR MAIL
Joseph Cleveland

GTE Products Corporation

Hawes Street

Towanda, PA 18848-0504

Gloria M. Collins

ASTM

1916 Race Street

Philadelphia, PA 19103

William C. Connors

Sundstrand Aviation Operations

Materials Science and

Engineering Department

4747 Harrison Avenue

P.O. Box 7002

Rockford, IL 61125-7002

John A. Coppola

Carborundum Company

P.O. Box 156

Niagara Falls, NY 14302

Normand D. Corbin

Norton Company, Advanced

Ceramics

Goddard Road

Northboro, MA 01532-1545

Douglas Corey

Allied-Signal Aerospace Company

2525 West 190th Street

MS:T52

Torrance, CA y0504-6099

Keith P. Costello

Chand/Kare Technical Ceramics

2 Coppage Drive

Worcester, MA 01603-1252

Ed L. Courtright

Pacific Northwest Laboratory

MS:K3-59

Richland, WA 99352 
Anna Cox

Mitchell Market Reports

P.O. Box 23

Monmouth Gwent NP5 4YG

UNITED KINGDOM AIR MAIL

J. Wesley Cox

BIRL

1801 Maple Avenue

Evanston, IL 60201-3135

Art Cozens

Instron Corporation

3414 Snowden Avenue

Long Beach, CA 90808

Robert C. Craft

American Ceramic Society, Inc.

735 Ceramic Place

P.O. Box 6136

Westerville, $\mathrm{OH} 43801-8720$

Mark Crawford

New Technology Week

4604 Monterey Drive

Annandale, VA 22003

Richard A. Cree

Markets \& Products, Inc.

P.O. Box 14328

Columbus, $\mathrm{OH}$ 43214-0328

Les Crittenden

Vesuvius McDanel

Box 560

Beaver Falls, PA 15010

William J. Croft

U.S. Army Materials

Technology Laboratory

405 Arsenal Street

Watertown, MA 02172

M. J. Cronin

Mechanical Technology, Inc.

968 Albany-Shaker Road

Latham, NY 12110
Gary M. Crosbie

Ford Motor Company

1430 Culver Avenue

S-2079, SRL Building

Dearborn, MI 48121-4036

Floyd W. Crouse, Jr.

U.S. Department of Energy

Morgantown Energy

Technology Center

Collins Ferry Road

P.O. Box 880

Morgantown, WV 26505

John Cuccio

Allied-Signal Aerospace Company

Garrett Auxiliary Power Division

P.O. Box 5227, MS:1302-2Q

Phoenix, AZ 85010

Raymond Cutler

Ceramatec, Inc.

2425 South 900 West

Salt Lake City, UT 84119

Stephen C. Danforth

Rutgers University

Ceramic Engineering Department

P.O. Box 909

Piscataway, NJ 08855-0909

Sankar Das Gupta

Electrofuel Manufacturing Co., Ltd.

9 Hanna Avenue

Toronto Ontario MGK-1W8

CANADA AIR MAIL

Charles Davis

Sverdrup Technology, Inc., MSFC

620 Discovery Drive

Huntsville, AL 35806 
Frank Davis

Allied Signal Aerospace Co.

7550 Lucerne Dr., \# 203

Middleburg Heights, OH 44130

Robert F. Davis

North Carolina State University

Materials Engineering Department

229 Riddick Laboratory

P.O. Box 7907

Raleigh, NC 27695

Thomas DeAngelis

Carborundum Company

Niagara Falls R\&D Center

P.O. Box 832

Niagara Falls, NY 14302

George DeBell

Ford Motor Company

Material Systems Reliability

Department

20000 Rotunda Drive

P.O. Box 2053, Room S-2023

Dearborn, MI 48121-2053

Michael DeLuca

AMP-AKZO

West Lane

Aquebogue, NY 11931

Gerald L. DePoorter

Colorado School of Mines

Metallurgical and Materials

Engineering Department

Golden, CO 80401

J. F. DeRidder

Omni Electro Motive, Inc.,

12 Seely Hill Road

Newfield, NY 14867

Nick C. Dellow

Materials Technology Publications

40 Sotheron Road

Watford Herts WD1 2QA

UNITED KINGDOM AIR MAIL
L. R. Dharani

University of Missouri-Rolla

224 M.E.

Rolla, MO 65401

Douglas A. Dickerson

Union Carbide Specialty Powders

1555 Main Street

Indianapolis, IN 46224

John Dodsworth

Vesuvius Research \& Development

Technical Ceramics Group

Box 560

Beaver Falls, PA 15010

B. Dogan

Institut fur Werkstofforschung

GKSS-Forschungszentrum

Geesthacht GmbH

Max-Planck-Strasse

D-2054 Geesthacht

GERMANY AIR MAIL

Jean-Marie Drapier

FN Moteurs S.A.

Material and Processing

B-4041 Milmort (Herstal)

BELGIUM AIR MAIL

Kenneth C. Dreitlein

United Technologies

Research Center

Silver Lane

East Hartford, CT 06108

Robin A.L. Drew

McGill University

Department of Mining and Metallurgical Engineering 3450 University Street

Montreal Quebec H3A 2A7

CANADA AIR MAIL 
Winston H. Duckworth

BCL

Columbus Division

505 King Avenue

Columbus, OH 43201-2693

K. F. Dufrane (5)

Battelle Columbus Laboratories

505 King Avenue

Columbus, OH 43201-2693

Bill Durako

Sundstrand Aviation Operations

Department 789-6

4747 Harrison Avenue

P.O. Box 7002

Rockford, IL 61125-7002

Ernest J. Duwell

212 Elm Street

Hudson, WI 54016

Chuck J. Dziedzic

Coors Ceramics Company

Structural Products Group

17750 West 32nd Avenue

Golden, CO 80401

Robert J. Eagan

Sandia National Laboratories

Engineered Materials \& Processes

Center

Org 1700

P.O. Box 5800

Albuquerque, NM 87185-5800

Jeffrey Eagleson

Lanxide Corporation

1001 Connecticut Avenue, N.W.

Washington, DC 20036

Harry E. Eaton

United Technologies Corporation

Research Center

Silver Lane

East Hartford, CT 06108
Harvill C. Eaton

Louisiana State University

Office of Research and Economic

Development

240 Thomas Boyd Hall

Baton Rouge, LA 70803

Christopher A. Ebel

Carborundum Company

Technology Division

P.O. Box 337

Niagara Falls, NY 14302

J. J. Eberhardt

U.S. Department of Energy

Office of Transportation Materials

CE-34

Washington, DC 20585

Jim Edler

Eaton Corporation

26201 Northwestern Highway

P.O. Box 766

Southfield, MI 48037

G. A. Eisman

Dow Chemical Company

Ceramics and Advanced Materials

52 Building Midland, MI 48667

William A. Ellingson

Argonne National Laboratory

Materials Science \& Technology

Division

9700 South Cass Avenue

Argonne, IL 60439

William S. Ellis

Machined Ceramics

629 N. Graham St.

N. Industrial Park

Bowling Green, KY 42101

Glen B. Engle

Nuclear \& Aerospace Materials

Corporation

16716 Martincoit Road

Poway, CA 92064 
Jeff Epstein

Ceramic Technologies, Inc.

2107 Jamara Lane

Houston, Ti 17077

Kenneth A. Epstein

Dow Chemical U.S.A.

Ceramics and Advanced Materials

800 Building

Midland, MI 48667

Art Erdemir

Argonne National Laboratory

Materials and Components

Technology Division

9700 South Cass Avenue

Argonne, IL 60439

E. M. Erwin

Lubrizol Corporation

1819 East 225th Street

Euclid, OH 44117

Kenji Esaki

Toyota Technical Center

U.S.A., Inc.

2000 Town Center, Suite 500

Southfield, MI 48075

John N. Eustis

U.S. Department of Energy

Industrial Energy Efficiency Division

CE-221

Washington, DC 20585

W. L. Everitt

Kyocera International, Inc.

8611 Balboa Avenue

San Diego, CA 92123

Gordon Q. Evison

332 South Michigan Avenue

Suite 1730

Chicago, IL 60604
John W. Fairbanks

U.S. Department of Energy

Advanced Propulsion Division

CE-322

Washington, DC 20585

Tim Fawcett

Dow Chemical Company

Central Research, Advanced

Ceramics Laboratory

1776 Building

Midland, MI 48674

Robert W. Fawley

Sundstrand Power Systems

Division of Sundstrand Corporation

4400 Ruffin Road

P.O. Box 85757

San Diego, CA 92186-5757

John J. Fedorchak

GTE Products Corporation

Hawes Street

Towanda, PA 18848-0504

Jeff T. Fenton

Vista Chemical Company

900 Threadneedle

Houston, TX 77079

Larry Ferrell

Babcock \& Wilcox

Old Forest Road

Lynchburg, VA 24505

Raymond R. Fessler

BIRL

Industrial Research Lab

1801 Maple Avenue

Evanston, IL 60201

Ross F. Firestone

Ross Firestone Company

188 Mary Street

Winnetka, IL 60093-1520 
Sharon L. Fletcher

Arthur D. Little, Inc.

15 Acorn Park

Cambridge, MA 02140-2390

Thomas F. Foltz

Textron Specialty Materials

2 Industrial Avenue

Lowell, MA 01851

Renee G. Ford

Materials and Processing Report

P.O. Box 72

Harrison, NY 10528

John Formica

Supermaterials

2020 Lakeside Avenue

Cleveland, $\mathrm{OH} 44114$

Edwin Frame

Southwest Research Institute

Division 2

P.O. Drawer 28510

San Antonio, TX 78284

Armanet Francois

French Scientific Mission

4101 Reservoir Road, N.W.

Washington DC 20007-2176

R. G. Frank

Technology Assessment Group 10793 Bentley Pass Lane

Loveland, OH 45140

David J. Franus

Forecast International

22 Commerce Road

Newtown, CT 06470

Marc R. Freedman

NASA Lewis Research Center

21000 Brookpark Road

MS:49-3

Cleveland, OH 44135
Douglas Freitag

LTV Missiles Division

P.O. Box 650003

MS:WT-21

Dallas, TX 75265

Brian R.T. Frost

Argonne National Laboratory

9700 South Cass Avenue

Building 900

Argonne, IL 60439

Lawrence R. Frost

Instron Corporation

100 Royall Street

Canton, MA 02021

George A. Fryburg

Norton/TRW Ceramics

7A-4 Raymond Avenue

Salem, NH 03079

Xiren Fu

Shanghai Institute of Ceramics

Chinese Academy of Sciences

1295 Ding-xi Road

Shanghai 200050

CHINA AIR MAIL

John Gahimer

P.O. Box 1302

Dublin, OH 43017

J. P. Gallagher

University of Dayton Research Institute

300 College Park, JPC-250

Dayton, OH 45469-0120

Garry Garvey

Coors Ceramics Company

Corporate World Headquarters

4545 McIntyre Street

Golden, CO 80403 
Joy A. Garwood

Norton Company

Advanced Ceramics

Goddard Roa J

Northboro, ':AA 01532-1545

Richard Gates

Natic nal Institute of Standards and Technology

Materials Bldg., A-256

Gaithersburg, MD 20899

H. Maury Gatewood

Reynolds Metals Company

Corpora :e R\&D

Fourth and Canal Streets

P.O. Box 27003

Richmonil, VA 23261

L. J. Gauckler

ETH-Zuri:h

Sonneggstıasse 5

CH-8092 Zurich 8092

SWITZERLAND AIR MAIL

Peter A. Gaydos (5)

Battelle Columbus Laboratories

505 King Avenue

Columbus, OH 43201-2693

George E. Gazza

U.S. Army Materials

Technology Laboratory

Ceramics Research Division

405 Arsenal Street

Watertown, MA 02172-0001

D. Gerster

CEA-DCOM

33 Rue De La Federation

Paris 75015

FRANCE AIR MAIL

John Ghinazzi

Coors Technical Ceramics Company

1100 Commerce Park Drive

Oak Ridge, TN 37830
Robert Giddings

General Electric Company

Research Laboratory

P.O. Box 8

Schenectady, NY 12301

A. M. Glaeser

University of California

Materials Science and Mineral Engineering

Lawrence Berkeley Laboratory

Hearst Mining Building

Berkeley, CA 94720

Joseph W. Glatz

Naval Air Propulsion Center

Systems Engineering Division

P.O. Box 7176, PE24

Trenton, NJ 08628

W. M. Goldberger

Superior Graphite Company

R\&D

2175 East Broad Street

Columbus, OH 43209

Allan E. Goldman

U.S. Graphite, Inc.

907 West Outer Drive

Oak Ridge, TN 37830

Stephen T. Gonczy

Allied Signal Research

P.O. Box 5016

Des Plaines, IL 60017

Jeffrey M. Gonzales

GTE Products Corporation

Hawes Street

Towanda, PA 18848-0504

Robert J. Gottschall

U.S. Department of Energy

ER-131, MS:G-236

Washington, DC 20545 
Earl Graham

Cleveland State University

Department of Chemical Engineering

Euclid Avenue at East 24th Street

Cleveland, $\mathrm{OH} 44115$

William A. Graham

Lanxide Corporation

P.O. Box 6077

Newark, DE 19714-6077

Robert E. Green, Jr.

Johns Hopkins University

Materials Science and Engineering Department

Baltimore, MD 21218

Lance Groseclose

General Motors Corporation

Allison Gas Turbine Division

P.O. Box 420, MS:W-5

Indianapolis, IN 46206

Thomas J. Gross

U.S. Department of Energy

Transportation Technologies

CE-30, Forrestal Bldg.

Washington, DC 20585

Mark F. Gruninger

Union Carbide Corporation

Specialty Powder Business

1555 Main Street

Indianapolis, IN 46224

Ernst Gugel

Cremer Forschungsinstitut

GmbH\&Co.KG

Oeslauer Strasse 35

D-8633 Roedental 8633

GERMANY AIR MAIL

Donald L. Guile

Corning Glass Works

SP-DV-1-9

Corning, NY 14831
John P. Gyekenyesi

NASA Lewis Research Center

21000 Brookpark Road, MS: 6-1

Cleveland, $\mathrm{OH} 44135$

Nabil S. Hakim

Detroit Diesel Corporation

13400 West Outer Drive

Detroit, MI 48239

Philip J. Haley

General Motors Corporation

Vehicular Engineering

P.O. Box 420, MS:T12A

Indianapolis, IN 46236

Judith Hall

Fiber Materials, Inc.

Biddeford Industrial Park

5 Morin Street

Biddeford, ME 04005

Y Hamano

Kyocera Corporation

5-22 Kitainoue-Cho, Higashino

Yamashina-Ku Kyoto 607

Japan AIR MAIL

Y. Harada

IIT Research Institute

Nometallic Materials and Composites

10 West 35th Street

Chicago, IL 60616

R. A. Harmon

25 Schalren Drive

Latham, NY 12110

Norman H. Harris

Hughes Aircraft Company

P.O. Box 800520

Saugus, CA 91380-0520

Alan M. Hart

Dow Chemical Company

Advanced Ceramics Laboratory

1776 Building

Midland, MI 48674 
Pat E. Hart

Battelle Pacific Northwest Laboratories

Ceramics and Polymers

Development Section

P.O. Box 999

Richland, WA 99352

Stephen D. Hartline

Norton Company

Advanced Ceramics

Goddard Road

Northboro, MA 01532-1545

Michael H. Haselkorn

Caterpillar, Inc.

Engineering Research Materials

Technical Center, Building E

P.O. Box 1875

Peoria, IL 61656-1875

N. B. Havewala

Corning, Inc.

SP-PR-11

Corning, NY 14831

John Haygarth

Teledyne WAA Chang Albany

P.O. Box 460

Albany, OR 97321

Norman L. Hecht

University of Dayton Research Institute

300 College Park

Dayton, OH 45469-0172

Peter W. Heitman

General Motors Corporation

Allison Gas Turbine Division

P.O. Box 420, MS:W-5

Indianapolis, IN 46206-0420

Robert W. Hendricks

Virginia Polytechnic Institute and State University

Materials Engineering Department

210 Holden Hall

Blacksburg, VA 24061-0237
Wynne Henley

Hertel Cutting Technologies, Inc.

1000 Clearview Court

Oak Ridge, TN 37830

Thomas L. Henson

GTE Products Corporation

Chemical \& Metallurgical Division

Hawes Street

Towanda, PA 18848

Thomas P. Herbell

NASA Lewis Research Center

21000 Brookpark Road

MS:49-3

Cleveland, OH 44135

Marlene Heroux

Rolls-Royce, Inc.

2849 Paces Ferry Road

Suite 450

Atlanta, GA 30339-3769

Robert L. Hershey

Science Management Corporation 1255 New Hampshire Ave., N.W.

Suite 1033

Washington, DC 20036

Hendrik Heystek

Bureau of Mines

Tuscaloosa Research Center

P.O. Box L

University, AL 35486

Robert V. Hillery

GE Aircraft Engines

One Neumann Way, M.D. H85

Cincinnati, OH 45215

Arthur Hindman

Instron Corporation

100 Royall Street

Canton, MA 02021 
Jon Hines

American Ceramic Society, Inc.

735 Ceramic Place

P.O. Box 6136

Westerville, OH 43081-6136

Hans Erich Hintermann

CSEM

Materials and Micromechanics

Division

Rue Breguet 2

Neuchatel 2000

SWITZERLAND AIR MAIL

Shinichi Hirano

Mazda R\&D of North America, Inc.

1203 Woodridge Avenue

Ann Arbor, MI 48105

Tommy Hiraoka

NGK Locke, Inc.

1000 Town Center

Southfield, MI 48075

John M. Hobday

U.S. Department of Energy

Morgantown Energy Technology Center

Collins Ferry Road

P.O. Box 880

Morgantown, WV 26507

Clarence Hoenig

Lawrence Livermore National

Laboratory

P.O. Box 808, Mail Code L-369

Livermore, CA 94550

Thomas Hollstein

Fraunhofer-Institut fur

Werkstoffmechanik IWM

Wohlerstrabe 11

D-7800 Freiburg

GERMANY AIR MAIL
Richard Holt

National Research Council of Canada Structures and Materials Laboratory Ottawa Ontario K1A 0R6

CANADA AIR MAIL

A. T. Hopper

Battelle Columbus Laboratories

Metals and Ceramics Department

505 King Avenue

Columbus, OH 43201-2693

Michael Horgan

Materials Engineering Magazine

1100 Superior Avenue

Cleveland, $\mathrm{OH} 44114$

Woodie Howe

Coors Technical Ceramics Company

1100 Commerce Park Drive

Oak Ridge, TN 37830

Stephen M. Hsu

National Institute of Standards

and Technology

Gaithersburg, MD 20899

Hann S. Huang

Argonne National Laboratory

9700 South Cass Avenue

Argonne, IL 60439-4815

Gene Huber

Precision Ferrites \& Ceramics

5576 Corporate Drive

Cypress, CA 90630

Harold A. Huckins

Princeton Advanced Technology, Inc.

56 Finley Road

Princeton, NJ 08540

Fred R. Huettic

Advanced Magnetics, Inc.

45 Corey Lane

Mendham, NJ 07945 
Brian K. Humphrey

Lubrizol Petroleum Chemicals Co.

3000 Town Center, Suite 1340

Southfield, MI 48075-1201

Robert M. Humrick

Dylon Ceramic Technoiogies

3100 Edgehill Road

Cleveland Heights, OH 44118

Lorretta Inglehart

National Science Foundation

Division of Materials Research

1800 "G" Street, N.W.,

Room 408

Washington, DC 20550

Michael S. Inoue

Kyocera International, Inc.

KII Library, 8611 Balboa Avenue

San Diego, CA 92123-1580

Osama Jadaan

Uni:ersity of Wisconsin-Platteville

General Engineering Division

1 University Fiaza

Platteville, WI 53818

Curtis A. Johnson

General Electric Company

Corporate R\&D

Room MB-187

P.O. Box 8

Schenectady, NY 12301

Sylvia Johnson

SRI Inter srational

333 Ravenswood Avenue

Menlo Park, CA 9.j025

Thomas A. Johnson

Lanxide Corporation

1300 Marrows Road

P.O. Box 6077

Newark, DE 19714-6077
W. S. Johnson

Indiana University

One City Centre, Suite 200

Bloomington, IN 47405

Walter F. Jones

Air Force Office of Scientific

Research

AFOSR/NA

Boiling Air Force Base

Washington, DC 20332-6448

Jill E. Jonkouski

U.S. Department of Energy

9800 South Cass Avenue

Argonne, IL 60439-4899

L. A. Joo

Great Lakes Research Corporation

P.O. Box 1031

Elizabethton, TN 37643

A. David Joseph

SPX Corporation

700 Terrace Point

Muskegon, MI 49443

Adam Jostsons

Australian Nuclear Science \& Technology Organization

Lucas Heights Research Laboratories

New Illawarra Road

Lucas Heights New South Wales

AUSTRALIA AIR MAIL

Matthew K. Juneau

Ethyl Corporation

451 Florida Street

Baton Rouge, LA 70801

Hartmut Kainer

Didier-Werke AG

Anlagentechnik Wiesbaden

Abraham-Lincoln-Str. 16

D-62. "riesbaden

GERMANY AIR MAIL 
Tom Kalamasz

Norton/TRW Ceramics

7A-4 Raymond Avenue

Salem, NH 03079

Lyle R. Kallenbach

Phillips Petroleum Company

R\&D

Mail Drop:123AL

Bartlesville, OK 74004

Nick Kamiya

Kyocera Industrial Ceramics Corporation

25 Northwest Point Blvd., Suite 450

Elk Grove Village, IL 60007-1030

Roy Kamo

Adiabatics, Inc.

3385 Commerce Park Drive

Columbus, IN 47201

Chih-Chun Kao

Industrial Technology Research Institute

Materials Research Laboratones

195 Chung-Hsing Road, Sec. 4

Chutung Hsinchu 31015 R.O.C.

TAIWAN AIR MAIL

Keith R. Karasek

Allied-Signal, Inc.

Fingineered Materials Research Center

50 East Algonquin Road

P.O. Box 5016

Des Plaines, IL 60017-5016

Martha R. Kass

U.S. Department of Energy

Oak Ridge Operations

Building $4500 \mathrm{~N}$

P.O. Box 2008, MS:6269

Oak Ridge, TN 37831-6269

Robert E. Kassel

Ceradyne, Inc.

3169 Redhill Avenue

Costa Mesa, CA 92626
Allan Katz

Wright Laboratory

Metals and Ceramics Division

WL/MLLM

Wright-Patterson AFB, OH 45433

R. Nathan Katz

Worcester Polytechnic Institute

Dept. of Mechanical Engineering

100 Institute Road

Worcester, MA 01609

Tony Kau hal

Detroit Diesel Corporation

13400 Outer Drive West

Speed Code: L-04

Detroit, MI 48239

Ted Kawaguchi

Tokai Carbon America, Inc.

375 Park Avenue, Suite 3802

New York, NY 10152

Noritsugu Kawashima

TOSHIBA Corporation

Mechanical Engineering Laboratory

4-1 Ukishima-Cho

Kawasaki-Ku Kawasaki 210

JAPAN AIR MAIL

Lisa Kempfer

Penton Publishing

Materials Engineering

1100 Superior Avenue

Cleveland, OH 44114-2543

Frederick L. Kennard, III

General Motors Corporation

AC Rochester

Department 32-24, EB

1300 North Dort Highway

Flint, MI 48556

David O. Kennedy

Lester B. Knight Cast

Metals Inc.

549 West Randolph Street

Chicago, IL 60661 
George Keros

Photon Physics

3175 Penobscot Building

Detroit, MI 48226

Pramod K. Khandelwal

General Motors Corporation

Allison Gas Turbine Division

P.O. Box 420, MS:W05

Indianapolis, IN 46206

Jim R. Kidwell

Allied-Signal Aerospace Company

Garrett Auxiliary Power Division

P.O. Box 5227

Phoenix, AZ 85010

Shin Kim

Korea Institute of Machinery \& Metals

66 Sangnam-dong, Changwon

Kyungnam 641-010

KOREA AIR MAIL

W. C. King

Mack Truck, Z-41

1999 Pennsylvania Avenue

Hagerstown, MD 21740

Carol Kirkpatrick

MSE, Inc.

CDIF Technical Library

P.O. Box 3767

Butte, MT 59702

Tony Kirn

Caterpillar, Inc.

Defense Products Department, JB7

Peoria, IL 61629

James D. Kiser

NASA Lewis Research Center

21000 Brookpark Road, MS:49-3

Cleveland, $\mathrm{OH} 44135$
Max Klein

Gas Research Institute

Thermodynamics

8600 West Bryn Mawr Avenue

Chicago, IL 60631

Richard N. Kleiner

Coors Ceramics Company

4545 McIntyre Street

Golden, CO 80403

Stanley J. Klima

NASA Lewis Research Center

21000 Brookpark Road

MS:6-1

Cleveland, OH 44135

Chris E. Knapp

Norton Advanced Ceramics

of Canada Ltd.

8001 Daly Street

Niagara Falls, Ontario L2G 6S2

CANADA AIR MAIL

Albert S. Kobayashi

University of Washington

Mechanical Engineering Department

MS:FU10

Seattle, WA 98195

Shigeki Kobayashi

Toyota Central Research Labs, Inc.

Nagakute Aichi 480-11

JAPAN AIR MAIL

Richard A. Kole

Z-Tech Corporation

8 Dow Road

Bow, NH 03304

E. Kostiner

University of Connecticut

Chemistry Department, U-60

Storrs, CT 06269-3060 
Joseph A. Kovach

Eaton Corporation

Manufacturing Technology Center

32500 Chardon Rd.

Willoughby Hills, OH 44094

Kenneth A. Kovaly

Technical Insights, Inc.

P.O. Box 1304

Fort Lee, NJ 07024-9967

Ralph G. Kraft

Spraying Systems Company

North Avenue at Schmale Road

Wheaton, IL 60189-7900

Arthur Kranish

Trends Publishing, Inc.

1079 National Press Building

Washington, DC 20045

A. S. Krieger

Radiation Science, Inc.

P.O. Box 293

Belmont, MA 02178

Pieter Krijgsman

Ceramic Design International

Holding B.V.

P.O. Box 68

Hattem 8050-AB

THE NETHERLANDS AIR MAIL

Waltraud M. Kriven

University of Illinois

Materials Science and

Engineering Department

105 South Goodwin Avenue

Urbana, IL 61801

Edward J. Kubel, Jr.

ASM International Advanced

Materials \& Processes

Materials Park, OH 44073
Dave Kupperman

Argonne National Laboratory

9700 South Cass Avenue

Argonne, IL 60439

Oh-Hun Kwon

Norton Company

Advanced Ceramics

Goddard Road

Northboro, MA 01532-1545

W. J. Lackey

Georgia Institute of Technology

Materials Science and Technology

Atlanta, GA 30332

Jai Lala

Tenmat Ltd., 40 Somers Road

Rugby Warwickshire CV22 7DH

ENGLAND AIR MAIL

Hari S. Lamba

General Motors Corporation

Electro-Motive Division

9301 West 55th Street

LaGrange, IL 60525

Richard L. Landingham

Lawrence Livermore National

Laboratory

Ceramics, Corrosion, and

Thermochemistry

P.O. Box 808, L-369

Livermore, CA 94550

Charles J. Landry

Chand Kare Technical Ceramics

712 Flat Hill Road

Lumenburg, MA 01462

James Lankford

Southwest Research Institute

Department of Materials Sciences

6220 Culebra Road

San Antonio, TX 78228-0510 
Stanley B. Lasday

Business News Publishing Co.

Manor Oak One

1910 Cochran Road, Suite 630

Pittsburgh, PA 15220

Mark S. Laser

Solar Turbines, Inc.

2211 Erie Street

San Diego, CA 92110

S. K. Lau

Carborundum Company

Technology Division

P.O. Box 832, B-100

Niagara Falls, NY 14302

Edward A. Lauder

Advanced Composite Materials

Corporation

1525 South Buncombe Road

Greer, SC 29651-9208

J. Lawrence Lauderdale

Babcock \& Wilcox

Contract Research Division

1850 "K" Street, Suite 950

Washington, DC 20006

Jean F. LeCostaouec

Textron Speciality Materials

2 Industrial Avenue

Lowell, MA 01851

Benson P. Lee

Interscience, Inc.

9718 Lake Shore Boulevard

Cleveland, OH 44108

Burtrand I. Lee

Clemson University

Department of Ceramic

Engineering

Olin Hall

Clemson, SC 29634-0907
June-Gunn Lee

KIST

Structural Ceramic Lab

P.O. Box 131, Cheong-Ryang

Seoul $130-650$

KOREA AIR MAIL

Ran-Rong Lee

Ceramics Process Systems

Corporation

155 Fortune Boulevard

Milford, MA 01757

Stan Levine

NASA Lewis Research Center 21000 Brookpark Road

MS:49-3

Cleveland, OH 44135

Alan V. Levy

Lawrence Berkeley Laboratory

One Cyclotron Road, MS:62-203

Berkeley, CA 94720

Aj-Kang Li

Materials Research Laboratories, ITRI

195-5 Chung-Hsing Road, Sec. 4 Chutung Hsinchu 31015 R.O.C.

TAIWAN AIR MAIL

Winston W. Liang

Hong Kong Industrial

Technology Centre Co. Ltd.

78 Tat Chee Avenue

4/F, HKPC Building

Howloon

HONG KONG AIR MAIL

Robert Licht

Norton Company

Advanced Ceramics

Goddard Road

Northboro, MA 01532-1545 
E. Lilley

Norton Company

Advanced Ceramics

Goddard Road

Northboro, MA 01532-1545

Laura J. Lindberg

Allied-Signal Aerospace Company

Garrett Fluid Systems Division

1300 West Warner

MS: 93-901-1207-4TT

P.O. Box 22200

Tempe, AZ 85284-2200

Leonard C. Lindgren

General Motors Corporation

Allison Gas Turbine Division

P.O. Box 420, Speed Code:T-20A

Indianapolis, IN 46206-0420

Hans A. Lindner

Cremer Forschungsinstitut

GmbH\&Co.KG

Oeslauer Strasse 35

D-8633 Rodental 8866

GERMANY AIR MAIL

Ronald E. Loehman

Sandia National Laboratories

Chemistry \& Ceramics

Department 1840

P.O. Box 5800

Albuquerque, NM 87185

Jeffrey C. Logas

Winona State University

Composite Materials Engineering

115 Pasteur Hall

Winona, MN 55987

Bill Long

Babcock \& Wilcox

P.O. Box 11165

Lynchburg, VA 24506
William D. Long

Wacker Chemicals (USA), Inc.

ESK Engineered Ceramics

50 Locust Avenue

New Canaan, CT 06840

L. A. Lott

EG\&G Idaho, Inc.

Idaho National Engineering

Laboratory

P.O. Box 1625

Idaho Falls, ID 83415-2209

Raouf O. Loutfy

MER Corporation

7960 South Kolb Road

Tucson, AZ 85706

Gordon R. Love

Aluminum Company of America

Alcoa Technical Center

Alcoa Center, PA 15069

Lydia Luckevich

Ortech International

2395 Speakman Drive

Mississauga Ontario L5K 1B3

CANADA AIR MAIL

James W. MacBeth

Carborundum Company

Structural Ceramics Division

P.O. Box 1054

Niagara Falls, NY 14302

H. MacLaren

General Electric Company

Thomson Laboratory, Materials

Engineering 36807

1000 Western Avenue

Lynn, MA 01910

George Maczura

Aluminum Company of America Industrial Chemicals Division

3450 Park Lane Drive

Pittsburgh, PA 15275-1119 
David Maginnis

Tinker AFB

OC-ALC/LIIRE

Tinker AFB OK 73145-5989

Frank Maginnis

Aspen Research, Inc.

220 Industrial Boulevard

Moore, OK 73160

Tai-il Mah

Universal Energy Systems, Inc.

Ceramics and Composites

Research

4401 Dayton-Xenia Road

Dayton, OH 45432

Kenneth M. Maillar

Barbour Stockwell Company

83 Linskey Way

Cambridge, MA 02142

Lorenzo Majno

Instron Corporation

100 Royall Street

Canton, MA 02021

S. G. Malghan

National Institute of Standards

and Technology

I-270 \& Clopper Road

Gaithersburg, MD 20899

Lars Malmrup

United Turbine $A B$

Box 13027

Malmo S-200 44

SWEDEN AIR MAIL

John Mangels

Ceradyne, Inc.

3169 Redhill Avenue

Costa Mesa, CA 92626

Russell V. Mann

Matec Applied Sciences, Inc.

75 South Street

Hopkinton, MA 01748
William R. Manning

Champion Aviation Products Division

Old Norris Road

P.O. Box 686

Liberty, SC 29657

Ken Marnoch

Amercom, Inc.

8928 Fullbright Avenue

Chatsworth, CA 91311

Robert A. Marra

Aluminum Company of America

Alcoa Technical Center

Advanced Ceramics Center - E

Alcoa Center, PA 15069

Chauncey L. Martin

3M Company

3M Center, Building 60-1N-01

St. Paul, MN 55144

Steven C. Martin

Advanced Refractory

Technologies, Inc.

699 Hertel Avenue

Buffalo, NY 14207

Kelly J. Mather

Williams International Corporation

2280 West Maple Road

P.O. Box 200

Walled Lake, MI 49088

James P. Mathers

3M Company

3M Center

Building 201-3N-06

St. Paul, MN 55144

Ron Mayville

Arthur D. Little, Inc.

15-163 Acorn Park

Cambridge, MA 02140 
F. N. Mazadarany

General Electric Company

Research Laboratory

Building K-1, Room MB-159

P.O. Box 8

Schenectady, NY 12301

James W. McCauley

Alfred University

NYS College of Ceramics

Binns-Merrill Hall

Alfred, NY 14802

Louis R. McCreight

2763 San Ramon Drive

Rancho Palos Verdes, CA 90274

Colin F. McDonald

McDonald Thermal Engineering

1730 Castellana Road

La Jolla, CA 92037

B. J. McEntire

Norton Company, TRW Ceramics

Goddard Road

Northboro, MA 01532-1545

Chuck McFadden

Coors Ceramics Company

600 9th Street

Golden, CO 80401

Thomas D. McGee

Iowa State University

Materials Science and

Engineering Department

110 Engineering Annex

Ames, IA 50011

Carol McGill

Corning Inc.

Sullivan Park, FR-02-08

Corning, NY 14831

T. C. McLaren

Cameron Forged Products Company

P.O. Box 1212

Houston, TX 77251-1212
James McLaughlin

Sundstrand Power Systems

4400 Ruffin Road

P.O. Box 85757

San Diego, CA 92186-5757

Matt McMonigle

U.S. Department of Energy

Improved Energy Productivity

Division

CE-231

Washington, DC 20585

J. C. McVickers

Allied-Signal Aerospace Company

Garrett Auxiliary Power Division

Bldg. 1303-206

P.O. Box 5227, MS:9317-2

Phoenix, AZ 85010

D. B. Meadowcroft

National Power Technology

and Environmental Centre

Kelvin Avenue

Leatherhead Surrey

KT22 7SE

ENGLAND AIR MAIL

Joseph J. Meindl

Reynolds International, Inc.

6603 West Broad Street

P.O. Box 27002

Richmond, VA 23261-7003

Michael D. Meiser

Allied-Signal Aerospace Company

Garrett Ceramic Components

Division

2525 West 190th Street

P.O. Box 2960, MS:T21

Torrance, CA $90509-2960$

George Messenger

National Research Council of

Canada

Engine Laboratory, Building M-7

Ottawa Ontario K1A OR6

CANADA AIR MAIL 
D. Messier

U.S. Army Materials Technology

Laboratory

SLCMT-EMC

405 Arsenal Street

Watertown, MA 02172-0001

Arthur G. Metcalfe

Arthur G. Metcalfe and

Associates, Inc.

2108 East 24th Street

National City, CA 91950

R. Metselaar

Eindhoven University

Centre for Technical Ceramics

P.O. Box 513

Eindhoven $5600 \mathrm{MB}$

THE NETHERLANDS AIR MAIL

David J. Michael

Harbison-Walker Refractories Company

P.O. Box 98037

Pittsburgh, PA 15227

Ken Michaels

Chrysler Motors Corporation

Ceramics Development

Metallurgical Processes

P.O. Box 1118, CIMS:418-17-09

Detroit, MI 48288

Bernd Michel

Institute of Mechanics

Fracture and Micromechanics

Department

P.O. Box 408

D-9010 Chemnitz

GERMANY AIR MAIL

David E. Miles

Commission of the European

Communities

rue de la Loi, 200

B-1049 Brussels

BELGIUM AIR MAIL
Carl E. Miller

AC Rochester

1300 North Dort Highway,

MS:32-31

Engineering Building B

Flint, MI 48556

Charles W. Miller, Jr.

Centorr Furnaces/Vacuum Industries

542 Amherst Street

Nashua, NH 03063

R. Mininni

Enichem America

2000 Cornwall Road

Monmouth Junction, NJ 08852

Michele V. Mitchell

Allied-Signal Aerospace

Company

Garrett Ceramic Components

Division

2525 West 190th Street

P. O. Box 2960, MS:T21

Torrance, CA $90501-2960$

Howard Mizuhara

WESGO

477 Harbor Boulevard

Belmont, CA 94002

Helen Moeller

Babcock \& Wilcox

P.O. Box 11165

Lynchburg, VA 24506-1165

Francois R. Mollard

Concurrent Technologies

Corporation

1450 Scalp Avenue

Johnstown, PA 15904-3374

Phil Mooney

Panametrics

NDE Division

221 Crescent Street

Waltham, MA 02254 
Geoffrey P. Morris

3M Company

3M Traffic Control Materials

Division

Bldg. 209-BW-10, 3M Center

St. Paul, MN 55144-1000

Jay A. Morrison

Rolls-Royce, Inc.

Engineering and Information

Center, Overlook 1

2849 Paces Ferry Road,

Suite 450

Atlanta, GA 30339-3769

Joel P. Moskowitz

Ceradyne, Inc.

3169 Redhill Avenue

Costa Mesa, CA 92626

Brij Moudgil

University of Florida

Material Science and

Engineering

Gainesville, FL 32611

Christoph J. Mueller

Sprechsaal Publishing

Group

P.O. Box 2962, Mauer 2

D-8630 Coburg

GERMANY AIR MAIL

Thomas W. Mullan

Vapor Technologies Inc.

345 Route 17 South

Upper Saddle River, NJ 07458

M. K. Murthy

MKM Consultants International

10 Avoca Avenue, Unit 1906

Toronto Ontario M4T 2B7

CANADA AIR MAIL
David L. Mustoe

Custom Technical Ceramics

8041 West I-70 Service Road,

Unit 6

Arvada, CO 80002

Curtis V. Nakaishi

U.S. Department of Energy

Morgantown Energy Technology

Center

Collins Ferry Road

P.O. Box 880

Morgantown, WV 26507-0880

Yoshio Nakamura

Faicera Research Institute

3-11-12 Misono

Sagamihara Kanagawa Pref.

JAPAN AIR MAIL

K. S. Narasimhan

Hoeganaes Corporation

River Road

Riverton, NJ 08077

Samuel Natansohn

GTE Laboratories, Inc.

40 Sylvan Road

Waltham, MA 02254

Robert Naum

Applied Resources, Inc.

P.O. Box 241

Pittsford, NY 14534

Malcolm Naylor

Cummins Engine Company, Inc.

P.O. Box 3005, Mail Code 50183

Columbus, IN 47202-3005

Jeffrey Neil

GTE Laboratories, Inc.

40 Sylvan Road

Waltham, MA 02254 
Fred A. Nichols

Argonne National Laboratory

9700 South Cass Avenue

MCT - Building 212

Argonne, IL 60439

H. Nickel

Furschungszentrum Jüelich (KFA)

P.O. Box 1913

Jüelich 1-5170 BRD NRW

GERMANY AIR MAIL

Dale E. Niesz

Rutgers University

Center for Ceramic Research

P.O. Box 909

Piscataway, NJ 08855-0909

David M. Nissley

United Technologies Corporation

Pratt \& Whitney Aircraft

400 Main Street, MS:163-10

East Hartford, CT 06108

Bruce E. Novich

Ceramics Process Systems Corporation

155 Fortune Boulevard

Milford, MA 01757

Daniel Oblas

50 Meadowbrook Drive

Bedford, MA 01730

Don Onanehi

Magnetic Bearings, Inc.

1908 Sussex Road

Blacksburg, VA 24060

Robert Orenstein

General Electric Company

55-112, River Road

Schenectady, NY 12345

Norb Osborn

Aerodyne Dallas

151 Regal Row,

Suite 120

Dallas, TX 75247
Richard Palicka

Cercom, Inc.

1960 Watson Way

Vista, CA 92083

Muktesh Paliwal

GTE Products Corporation

Hawes Street

Towanda, PA 18848

Joseph E. Palko

General Electric Company

55-113, River Road

Schenectady, NY 12345

Joseph N. Panzarino

Norton Company

Advanced Ceramics

Goddard Road

Northboro, MA 01532-1545

Pellegrino Papa

Corning Inc.

MP-WX-02-1

Corning, NY 14831

Terry Paquet

Boride Products, Inc.

2879 Aero Park Drive

Traverse City, MI 49684

E. Beth Pardue

MPC

8297 Williams Ferry Road

Lenoir City, TN 37771

Soon C. Park

3M Company

3M Center

Building 142-4N-02

P.O. Box 2963

St. Paul, MN 55144

Hartmut Paschke

Schott Glaswerke

Christoph-Dorner-Strasse 29

D-8300 Landshut

GERMANY AIR MAIL 
James W. Patten

Cummins Engine Company, Inc.

Materials Engineering

P.O. Box 3005, Mail

Code 50183

Columbus, IN 47202-3005

Robert A. Penty

Eastman Kodak Company

$\mathrm{KAD} / \mathrm{D} 73$ - 35612

901 Elmgrove Road

Rochester, NY 14653

Robert W. Pepper

Textron Specialty Materials

2 Industrial Avenue

Lowell, MA 01851

Peter Perdue

Detroit Diesel Corporation

Research Advanced Development

Group

13400 Outer Drive West

Speed Code L-04

Detroit, MI 48239-4001

Bruce Peters

Dow Chemical Company

Building 52

Midland, MI 48667

John J. Petrovic

Los Alamos National Laboratory

Group MST-4, MS:G771

Los Alamos, NM 87545

Frederick S. Pettit

University of Pittsburgh

Pittsburgh, PA 15261

Ben A. Phillips

Phillips Engineering Company

721 Pleasant Street

St. Joseph, MI 49085
Richard C. Phoenix

Ohmtek, Inc.

2160 Libe rty Drive

Niagara F lls, NY 14302

Bruce J. Pletka

Michigan Technological

University

Metallurgical and Materials

Engineering Department

Houghton, MI 49931

John P. Pollinger

Allied-Signal Aerospace Company

Garrett Ceramic Components

Division

2525 West 190th Street

P.O. Box 2960, MS:T21

Torrance, CA $90509-2960$

P. Popper

High Technology Ceramics

International Journal

22 Pembroke Drive

Westlands Newcastle-under-Lyme

Staffs ST5 2JN

ENGLAND

AIR MAIL

F. Porz

Universitat Karlsruhe

Institut fur Keramik Im

Maschinendau

Postfach 6980

D-7500 Karlsruhe

GERMANY AIR MAIL

Harry L. Potma

Royal Netherlands Embassy

Science and Technology

4200 Linnean Avenue, N.W.

Washington, DC 20008 
Bob R. Powell

General Motors Research

Laboratories

Metallurgy Department

30500 Mound Road

Box 9055

Warren, MI 48090-9055

Stephen C. Pred

ICD Group, Inc.

1100 Valley Brook Avenue

Lyndhurst, NJ 07071

Karl M. Prewo

United Technologies Research

Center

411 Silver Lane

MS:24

East Hartford, CT 06108

Peter E. Price

Industrial Materials

Technology, Inc.

P.O. Box 9565

Andover, MA 01810

Joseph M. Proud

GTE Laboratories, Inc.

Materials Science Laboratory

40 Sylvan Road

Waltham, MA 02254

Vimal K. Pujari

Norton Company

Advanced Ceramics

Goddard Road

Northboro, MA 01532-1545

George Quinn

National Institute of

Standards and Technology

Ceramics Division, Bldg. 223

Gaithersburg, MD 20899
Ramas V. Raman

Ceracon, Inc.

1101 North Market Boulevard,

Suite 9

Sacramento, CA 95834

Charles F. Rapp

Owens Corning Fiberglass

2790 Columbus Road

Granville, OHI 43023-1200

Dennis W. Readey

Colorado School of Mines

Department of Metallurgy and Materials Engineering

Golden, CO 80401

Wilfred J. Rebello

PAR Enterprises, Inc.

12601 Clifton Hunt Lane

Clifton, VA 22024

Harold Rechter

Chicago Fire Brick Company

R\&D

7531 South Ashland Avenue

Chicago, IL 60620

Robert R. Reeber

U.S. Army Research Office

P.O. Box 12211

Research Triangle Park, NC 27709

K. L. Reifsnider

Virginia Polytechnic Institute and State University

Department of Engineering

Science and Mechanics

Blacksburg, VA 24061

Paul E. Rempes

McDonnell Douglass

Aircraft Company

P.O. Box 516,

Mail Code:0642263

St. Louis, MO 63166-0516 
Gopal S. Revankar

John Deere Company

Metals Research

3300 River Drive

Moline, IL 61265

K. T. Rhee

Rutgers University

Mechanical Engineering

P.O. Box 909

Piscataway, NJ 08854

James Rhodes

Advanced Composite Materials

Corporation

1525 South Buncombe Road

Greer, SC 29651

Roy W. Rice

W. R. Grace and Company

7379 Route 32

Columbia, MD 21044

David W. Richerson

2093 East Delmont Drive

Salt Lake City, UT 84117

Tomas Richter

J. H. France Refractories

1944 Clarence Road

Snow Shoe, PA 16874

Michel Rigaud

Ecole Polytechnique

Campus Universite De Montreal

P.O. Box 6079, Station A

Montreal, P.Q Quebec H3C 3A7

CANADA AIR MAIL

R. E. Riman

Rutgers University

Ceramics Engineering

Department

P.O. Box 909

Piscataway, NJ 08855-0909
Barry Ringstrom

Superior Graphite Company

P.O. Box 2373

Smyrna, GA 30081

John E. Ritter

University of Massachusetts

Mechanical Engineering

Department

Amherst, MA 01003

Frank L. Roberge

Allied-Signal Aerospace

Company

Garrett Auxiliary Power

Division

P.O. Box 5227

Phoenix, AZ 85010

W. Eric Roberts

Advanced Ceramic Technology, Inc.

990 "F" Enterprise Street

Orange, CA 92667

Y. G. Roman

TNO TPD Keramick

P.O. Box 595

Einhoven 5600 AN

HOLLAND AIR MAIL

Michael Rossetti

Arthur D. Little, Inc.

15 Acorn Park

Cambridge, MA 01240

Barry R. Rossing

Lanxide Corporation

P.O. Box 6077

Newark, DE 19714-6077

Steven L. Rotz

Lubrizol Corporation

29400 Lakeland Boulevard

Wickliffe, OH 44092 
Bruce Rubinger

Global Competitiveness, Inc.

One Devonshire Place,

Suite 1011

Boston, MA 02109

Robert Ruh

Wright Laboratory

WLMLLM

Wright-Patterson AFB, OH 45433

Robert J. Russell

17 Highgate Road

Framingham, MA 01701

L. William Sahley

Supermaterials Company

24400 Highland Road

Richmond Heights, OH 44143

Jon Salem

NASA Lewis Research Center 21000 Brookpark Center

Cle':eland, $\mathrm{OH} 44135$

W. A. Sanders

NASA Lewis Research Center 21000 Brookpark Road,

MS:49-3

Cleveland, OH 44135

J. Saniar

North Carolina A\&T State

University

Department of Mechanical

Engineering

Greensboro, NC 27411

Yasushi Sato

NGK Spark Plugs (U.S.A.), Inc. 1200 Business Center Drive,

Suite 300

Mt. Prospect, IL 60056
Maxine L. Savitz

Allied-Signal Aerospace Company

Garrett Ceramic Components

Division

2525 West 190th Street

P. O. Box 2960, MS:T21

Torrance, CA $90509-2960$

Ashok Saxena

GTRI

Materials Engineering

Atlanta, GA 30332-0245

David W. Scanlon

Instron Corporation

100 Royall Street

Canton, MA 02021

Charles A. Schacht

Schacht Consulting Services

12 Holland Road

Pittsburgh, P.A 15235

James Schienle

Allied-Signal Aerospace

Company

Garrett Auxiliary Power

Division

2739 East Washington Street

P.O. Box 5227, MS:1302-2P

Phoenix, AZ 85010

John C. Schneider

San Juan Technologies

P.O. Box 49326

Colorado Springs, CC 80949-9326

Gary Schnittgrund

Rocketdyne, BA05

6633 Canoga Avenue

Canoga Park, CA 91303

Mark Schomp

Lonza, Inc.

Corporate Headquarters

17-17 Route 208

Fair Lann, NJ 07410 
Joop Schoonman

Delft University of Technology

Laboratory for Inorganic Chemistry

P.O. Box 5045

2600 GA Delft

THE NETHERLANDS AIR MAIL

John Schuldies

Industrial Ceramic Technology, Inc.

37 Enterprise Drive

Ann Arbor, MI 48103

Robert B. Schulz

U.S. Department of Energy

Office of Transportation Materials

CE-34

Washington, DC 20585

Murray A. Schwartz

Materials Technology Consulting, Inc.

30 Orchard Way, North

Potomac, MD 20854

Peter Schwarzkopf

SRI International

333 Ravenswood Avenue

Menlo Park, CA 94025

William T. Schwessinger

Multi-Arc Scientific Coatings

1064 Chicago Road

Troy, MI 48083-4297

W. D. Scott

University of Washington

Materials Science Department

Mail Stop:FB10

Seattle, WA 98195

Nancy Scoville

Thermo Electron Technologies

74 West Street

P.O. Box 9046

Waltham, MA 02254-9046
Thomas M. Sebestyen

U.S. Department of Energy

Advanced Propulsion Division

CE-322, Forrestal Building

Washington, DC 20585

Brian Seegmiller

Coors Ceramics Company

600 9th Street

Golden, CO 80401

T. B. Selover

AICRE/DIPPR

3575 Traver Road

Shaker Heights, OH 44122

J. H. Selverian

GTE Laboratories, Inc.

40 Sylvan Road

Waltham, MA 02254

Charles E. Semler

Semler Materials Services

4160 Mumford Court

Columbus, $\mathrm{OH} 43220$

Thomas Service

Service Engineering Laboratory

324 Wells Street

Greenfield, MA 01301

Kish Seth

Ethyl Corporation

R\&D Laboratories

P.O. Box 341

Baton Rouge, LA 70821

Karleen Seybold

Allied-Signal Aerospace Company

Garrett Auxiliary Power Division

P.O. Box 5227

Phoenix, AZ 85010

William J. Shack

Argonne National Laboratory

9700 South Cass Avenue

Building 212

Argonne, IL 60439 
Peter T. B. Shaffer

Technical Ceramics

Laboratories, Inc.

4045 Nine/McFarland Drive

Alpharetta, GA 30201

Richard K. Shaltens

NASA Lewis Research Center

21000 Brookpark Road,

MS:301-2

Cleveland, OH 44135

Robert S. Shane

1904 NW 22nd Street

Stuart, FL 34994-9270

Daniel Shanefield

Rutgers University

Ceramics Engineering Department

P.O. Box 909

Piscataway, NJ 08855-0909

Ravi Shankar

Chromalloy

Research and Technology

Division

Blaisdell Road

Orangeburg, NY 10962

Terence Sheehan

Alpex Wheel Company

727 Berkley Street

New Milford, NJ 07646

Dinesh K. Shetty

University of Utah

304 EMRO, Dept. of Materials

Science and Engineering

Salt Lake City, UT 84112

Masahide Shimizu

Ceramic Society of Japan

2-2-503 Takiyama 6-chome

Higashikurume-Shi Tokyo 203

JAPAN AIR MAIL
John Shipinski

Toyota Technical Center

U.S.A., Inc.

Technical Research Department 2000 Town Center, Suite 500

Southfield, MI 48075

Thomas Shreves

American Ceramic Society, Inc.

Library

735 Ceramic Place

P.O. Box 6136

Westerville, OH 43081-2821

Jack D. Sibold

Coors Ceramics Company

Contracts for Corporate

Technology

4545 McIntyre Street

Golden, CO 80403

Johann Siebels

Volkswagen AG

Werkstofftechnologie

Postfach

3180 Wolfsburg 1

GERMANY

AIR MAIL

George H. Siegel

Point North Associates, Inc.

P.O. Box 907

Madison, NJ 07940

Richard Silberglitt

Technology Assessment and Transfer, Inc.

133 Defense Highway, \#212

Annapolis, MD 21401

Mary Silverberg

Norton Company

Advanced Ceramics Library

Goddard Road

Northboro, MA 01532-1545 
Gurpreet Singh

Department of the Navy

Internal Combustion \& Gas

Turbine Engine Division

Code 56X31

Washington, DC 20362-5101

Maurice J. Sinnott

University of Michigan

Chemical and Metallurgical

Engineering

5106 IST Building

Ann Arbor, MI 48109-2099

John Skildum

3M Company

3M Center

Building 224-2S-25

St. Paul, MN 55144

David P. Smith

Hoskins, Rees \& Smith

1910 Cochran Road

Manor Oak II, Suite 658

Pittsburgh, PA 15220

Richard H. Smoak

Smoak \& Associates

3554 Hollyslope Road

Altadena, CA 91001-3923

Jay R. Smyth

Allied-Signal Aerospace Company

Garrett Auxiliary Power Division

2739 East Washington Street

P.O. Box 5227

MS:93-173/1303-207

Phoenix, AZ 85010

Rafal A. Sobotowski

British Petroleum Company

Technical Center, Broadway

3092 Broadway Avenue

Cleveland, $\mathrm{OH} 44115$
A. G. Solomah

SAC International Ltd.

1445 Bonhill Road, \# 13

Mississauga Ontario L5T 1V3

CANADA AIR MAIL

S. Somiya

Nishi Tokyo University

3-7-19 Seijo, Setagaya

Tokyo 157

JAPAN AIR MAIL

Boyd W. Sorenson

DuPont Lanxide Composites

1300 Marrows Road

P.O. Box 6077

Neward, DE 19707

Charles A. Sorrell

U.S. Department of Energy

Advanced Industrial Concepts

Division

CE-232

Washington, DC 20585

C. Spencer

EA Technology

Capenhurst Chester

CH1 6ES

UNITED KINGDOM AIR MAIL

Allen Spizzo

Hercules, Inc.

Hercules Plaza

Wilmington, DE 19894

Richard M. Spriggs

Alfred University

Center for Advanced Ceramic

Technology

Alfred, NY 14802

Charles Spuckler

NASA Lewis Research Center 21000 Brookpark Road

MS: 5-11

Cleveland, OH 44135-3191 
M. Srinivasan

Material Solutions

P.O. Box 663

Grand Island, NY 14702-0663

Gordon L. Starr

Cummins Engine Company, Inc.

Design \& Technology

P.O. Box 3005

Mail Code 50182

Columbus, IN 47202-3005

Jim Stevenson

Windrock, Incorporated

835 Innovation Drive

Knoxville, TN 37932

Tom Stillwagon

Allied-Signal Inc.

Ceramic Components

2525 West 190th Street

P. O. Box 2960, MS:T21

Torrance, CA $90509-2960$

Harold L. Stocker

General Motors Corporation

Allison Gas Turbine Division

P.O. Box 420

Indianapolis, IN 46206

H. M. Stoller

TPL Inc.

3754 Hawkins, N.E.

Albuquerque, NM 87109

Paul D. Stone

Dow Chemical USA

1776 "Eye" Street, N.W.,

Suite 575

Washington, DC 20006

Roger S. Storm

Carborundum Company

Technology Division

P.O. Box 337

Niagara Falls, NY 14302-0337
F. W. Stringer

Aero \& Industrial

Technology Ltd.

P.O. Box 46, Wood Top

Burnley Lancashire BB11 4BX

UNITED KINGDOM AIR MAIL

Thomas N. Strom

NASA Lewis Research Center

21000 Brookpark Road

MS:86-6

Cleveland, $\mathrm{OH} 44135$

M. F. Stroosnijder

Institute for Advanced

Materials

Joint Research Centre

21020 Ispra (VA)

ITALY AIR MAIL

Karsten Styhr

30604 Ganado Drive

Rancho Palos Verdes, CA 90274

T. S. Sudarshan

Materials Modification, Inc.

2929-P1 Eskridge Center

Fairfax, VA 22031

M. J. Sundaresan

University of Miami

Mechanical Engineering

Department

P.O. Box 248294

Coral Gables, FL 33124

Patrick L. Sutton

U.S. Department of Energy

Advanced Propulsion Division

CE-322

Washington, DC 20585

Willard H. Sutton

United Technologies Corporation

Research Center, MS:24

Silver Lane

East Hartford, CT 06108 
Ron Sviben

100 Indel Avenue

Rancocas, NJ 08073

J. J. Swab

U.S. Army Materials Technology Laboratory

Ceramics Research Division

SLCMT-EMC

405 Arsenal Street

Watertown, MA 02172

Robert E. Swanson

Metalworking Technology, Inc.

1450 Scalp Avenue

Johnstown, PA 15904

Scott L. Swartz

Battelle Columbus

Laboratories

Metals and Ceramics

505 King Avenue

Columbus, OH 43201

Steve Szaruga

Air Force Wright Aeronautical

Laboratory

Materials Directorate

WL/MLBC

Wright-Patterson

AFB, OH 45433-6533

Yo Tajima

NGK Spark Plug Company, Ltd.

NTK Technical Ceramic Division

2808 Iwasaki

Komaki-shi Aichi-ken 485

JAPAN AIR MAIL

Fred Teeter

5 Tralee Terrace

East Amherst, NY 14051

Monika O. Ten Eyck

Carborundum Company

Technology Division

P.O. Box 832

Niagara Falls, NY 14302
David F. Thompson

Corning Glass Works

SP-DV-02-1

Corning, NY 14831

Merle L. Thorpe

Hobart Tafa Technologies, Inc.

146 Pembroke Road

Concord, NH 03301

T. Y. Tien

University of Michigan

Materials Science and

Engineering Department

Dow Building

Ann Arbor, MI 48103

D. M. Tracey

Norton Company

Advanced Ceramics

Goddard Road

Northboro, MA 01532-1545

Dick Trippett

General Motors Corporation

Allison Gas Turbine Division

P.O. Box 420, MS:W-16

Indianapolis, IN 46206-0420

L. J. Trostel, Jr.

Box 199

Princeton, MA 01541

W. T. Tucker

General Electric Company

Corporate R\&D

Building K1-4C35

P.O. Box 8

Schenectady, NY 12301

Masanori Ueki

Nippon Steel Corporation

Central R\&D Bureau

1618 Ida

Nakahara-Ku Kawasaki 211

JAPAN AIR MAIL 
Filippo M. Ugolini

ATA Studio

Via Degli Scipioni, 268A

ROMA 00192

ITALY AIR MAIL

Donald L. Vaccari

General Motors Corporation

Allison Gas Turbines

P.O. Box 420

Speed Code $\$ 49$

Indianapolis, IN 46206-0420

Carl F. Van Conant

Boride Products, Inc.

2879 Aero Park Drive

Traverse City, MI 49684

Marcel H. Van De Voorde

Commission of the European

Communities

Institute for Advanced

Materials

Joint Research Centre

P.O. Box 2

1755 ZG Petten

THE NETHERLANDS AIR MAIL

O. Van Der Biest

Katholieke Universiteit Leuven

Departement Metaalkunde en

Toegepaste

de Croylaan 2

B-3030 Leuven

BELGIUM AIR MAIL

Michael Vannier

Washington University,

St. Louis

Mallinckrodt Institute of

Radiology

510 South Kings Highway

St. Louis, MO 63110
Stan Venkatesan

Southern Coke \& Coal

Corporation

P.O. Box 52383

Knoxville, TN 37950

V. Venkateswaran

Carborundum Company

Niagara Falls R\&D Center

P.O. Box 832

Niagara Falls, NY 14302

Dennis Viechnicki

U.S. Army Materials Technology

Laboratory

405 Arsenal Street

Watertown, MA 02172-0001

Ted Vojnovich

U.S. Department of Energy

Office of Energy Research,

ER-42

Washington, DC 20585

John D. Volt

E. I. Dupont de Nemours \&

Company, Inc.

P.O. Box 80262

Wilmington, DE 19880

John B. Wachtman

Rutgers University

Ceramics Department

P.O. Box 909

Piscataway, NJ 08855

Shigetaka Wada

Toyota Central Research

Labs, Inc.

Nagakute Aichi 480-11

JAPAN AIR MAIL 
Janet Wade

Allied-Signal Aerospace

Company

Garrett Auxiliary Power

Division, Department 93-772

P.O. Box 5227, MS:1303-2

Phoenix, AZ 85010

Richard L. Wagner

Ceramic Technologies, Inc.

537 Turtle Creek South Drive,

Suite 24D

Indianapolis, IN 46227

J. Bruce Wagner, Jr.

Arizona State University

Center for Solid State Science

Tempe, AZ 85287-1704

Daniel J. Wahlen

Kohler, Co.

444 Highland Drive

Kohler, WI 53044

Ingrid Wahlgren

Royal Institute of Technology

Studsvik Library

S-611 82 Nykoping

SWEDEN AIR MAIL

Ron H. Walecki

Allied-Signal Aerospace Company

Garrett Ceramic Components Division

2525 West 190th Street

P.O. Box 2960, MS:T21

Torrance, CA 90509-2960

Michael S. Walsh

Vapor Technologies Inc.

2100 Central Avenue

Boulder, CO 80301

Chien-Min Wang

Industrial Technology Research Institute

Materials Research Laboratories

195 Chung-Hsing Road, Sec. 4

Chutung Hsinchu 31015 R.O.C.

TAIWAN AIR MAIL
Robert M. Washburn

ASMT

11203 Colima Road

Whittier, CA 90604

Gerald Q. Weaver

Carborundum Specialty Products

42 Linus Allain Avenue

Gardner, MA 01440-2478

Karen E. Weber

Detroit Diesel Corporation

Technology and Planning

13400 West Outer Drive

Detroit, MI 48239-4001

J. K. Weddell

DuPont Fibers

Experimental Station, E302

Wilmington, DE 19880-0302

R. W. Weeks

Argonne National Laboratory

MCT-212

9700 South Cass Avenue

Argonne, IL 60439

Ludwig Weiler

ASEA Brown Boveri AG

Corporate Research

Eppelheimer Str. 82

D-6900 Heidelberg

GERMANY AIR MAIL

James Wessel

Dow Corning Corporation

1800 "M" Street, N.W.,

Suite 325 South

Washington, DC 20036

Robert D. West

Therm Advanced Ceramics

P.O. Box 220

Ithaca, NY 14851 
Thomas J. Whalen

Ford Motor Company

26362 Harriet

Dearborn Heights, MI 48127

Ian A. White

Hoeganaes Corporation

River Road

Riverton, NJ 08077

Alan Whitehead

General Electric Company

1 River Road, 55-111

Schenectady, NY 12345

Sheldon M. Wiederhorn

National Institute of

Standards and Technology

Building 223, Room A329

Gaithersburg, MD 20899

John F. Wight

Alfred University

McMahon Building

Alfred, NY 14802

D. S. Wilkinson

McMaster University

Materials Science and

Engineering Department

1280 Main Street, West

Hamilton Ontario L8S 4L7

CANADA AIR MAIL

James C. Williams

General Electric Company

Engineering Materials

Technology Labs

One Neumann Way

Mail Drop: $\mathrm{H85}$

Cincinnati, OH 45215-6301

Steve J. Williams

RCG Hagler Bailly, Inc.

1530 Wilson Boulevard,

Suite 900

Arlington, VA 22209-2406
Thomas A. Williams

National Renewable Energy

Laboratory

1617 Cole Boulevard

Golden, CO 80401

Craig A. Willkens

Norton Company

Advanced Ceramics

Goddard Road

Northboro, MA 01532-1545

Roger R. Wills

TRW, Inc.

Valve Division

1455 East 185th Street

Cleveland, $\mathrm{OH} 44110$

David Gordon Wilson

Massachusetts Institute of

Technology

Mechanical Engineering

Department

77 Massachusetts Avenue, Room 3-455

Cambridge, MA 02139

Matthew F. Winkler

Seaworthy Systems, Inc.

P.O. Box 965

Essex, CT 06426

Gerhard Winter

Hermann C. Starck Berlin GmbH, Werk Goslar

P.O. Box 2540

D-3380 Goslar 3380

GERMANY AIR MAIL

W. L. Winterbottom

Ford Motor Company

Material Systems Reliability

Department

20000 Rotunda Drive

SRL, Room E-3182

P.O. Box 2053

Dearborn, MI 48121 
William T. Wintucky

NASA Lewis Research Center

Terrestrial Propulsion Office

21000 Brookpark Road, MS:86-6

Cleveland, $\mathrm{OH} 44135$

David G. Wirth

Coors Ceramics Company

600 9th Street

Golden, CO 80401

Thomas J. Wissing

Eaton Corporation

Engineering \& Research Center

P.O. Box 766

Southfield, MI 48037

James C. Withers

MER Corporation

7960 South Kolb Road

Building $\mathrm{F}$

Tucson, AZ 85706

Dale E. Wittmer

Southern Illinois University

Mechanical Engineering

Department

Carbondale, IL 62901

Warren W. Wolf

Owens Corning Fiberglass

2790 Columbus Road, Route 16

Granville, OH 43023

Egon E. Wolff

Caterpillar Inc.

Technical Center

P.O. Box 1875

Peoria, Il 61656-1875

George W. Wolter

Howmet Turbine Components

Corporation

Technical Center

699 Benston Road

Whitehall, MI 49461
James C. Wood

NASA Lewis Research Cente!

21000 Brookpark Road

MS:86-6

Cleveland, $\mathrm{OH} 44135$

Marrill Wood

LECO Corporation

Augusta Division

P.O. Box 211688

Augusta, GA 30917-1688

Wayne L. Worrell

University of Pennsylvania

Department of Materials

Science and Engineering

3231 Walnut Street

Philadelphia, PA 19104

John F. Wosinski

Corning Inc.

ME-2 E-5 H8

Corning, NY 14830

Ian G. Wright

Battelle Columbus Laboratories 505 King Avenue

Columbus, OH 43201

Ruth Wroe

ERDC

Metals \& Materials Industries

Division

Capenhurst Chester CH1 6ES

ENGLAND AIR MAIL

Bernard J. Wrona

Advanced Composite Materials

Corporation

1525 South Buncombe Road

Greer, SC 29651

Carl C. M. Wu

Naval Research Laboratory

Ceramic Branch, Code 6373

Washington, DC 20375 
John C. Wurst

University of Dayton Research Institute

300 College Park

Dayton, OH 45469-0101

Neil Wyant

ARCH Development Corp.

9700 South Cass Avenue

Building 202

Argonne, IL 60439

Roy Yamamoto

Texaco Inc.

P.O. Box 509

Beacon, NY 12508-0509

John Yamanis

Allied-Signal, Inc.

Ceramics Program

P.O. Box 1021

Morristown, NJ 07962-1021

Harry C. Yeh

Allied-Signal Aerospace

Company

Garrett Ceramic Components

Division

2525 West 190th Street

P.O. Box 2960, MS:T21

Torrance, CA $90509-2960$

Hiroshi Yokoyama

Hitachi Research Lab

4026 Kuji-Cho

Hitachi-shi Ibaraki 319-12

JAPAN AIR MAIL

Thomas M. Yonushonis

Cummins Engine Company, Inc.

P.O. Box 3005

Mail Code 50183

Columbus, IN 47202-3005
Thomas J. Yost

Corning, Inc.

Technical Products Division,

Main Plant 21-1-2

Corning, NY 14831

Jong Yung

Sundstrand Aviation Operations

Department 789-6

4747 Harrison Avenue

Rockford, IL. 61125

A. L. Zadoks

Caterpillar Inc.

Technical Center, Building L

P.O. Box 1875

Peoria, IL 61656-1875

Avi Zangvil

University of Illinois

Materials Research Laboratory

104 South Goodwin Avenue

Urbana, IL 61801

Charles H. Zenuk

Transtech

1340 North Via Ronda Oeste

6569 East Calle Cavalier

Tucson, AZ 85715-4830

Carl Zweben

General Electric Company

P.O. Box 8555, VFSC/V4019

Philadelphia, PA 19101

Klaus M. Zwilsky

National Research Council

National Materials Advisory Board

2101 Constitution Avenue

Washington, DC 20418

DOE Oak Ridge Operations

Assistant Manager for Energy

Research and Development

P.O. Box 2001

Oak Ridge, TN 37831-8501 
Department of Energy (2)

Office of Scientific and

Technical Information

Office of Information Services

p.O. Box 62

Oak Ridge, TN 37831 

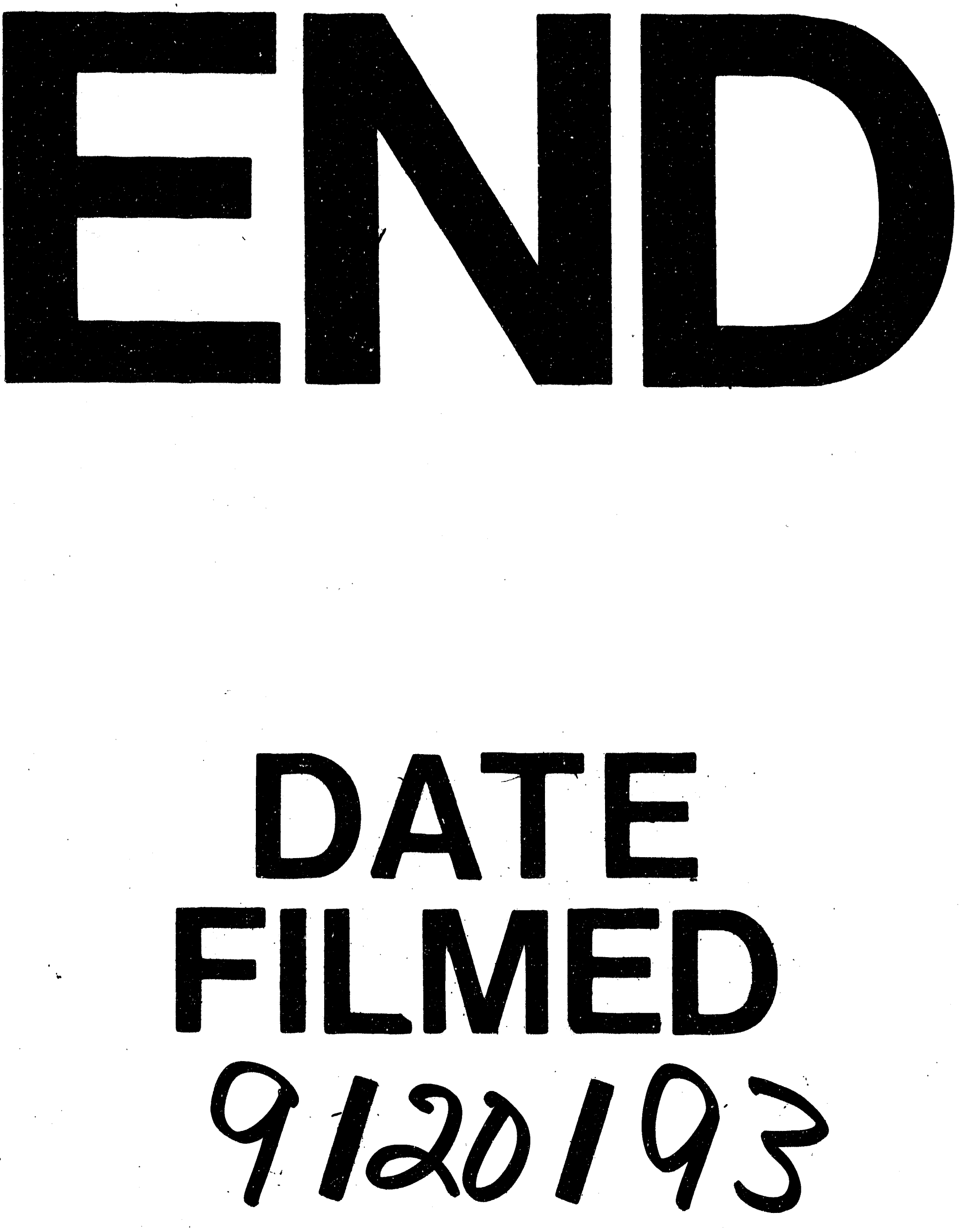
